\title{
Systematic review and meta-analysis of chordal replacement versus leaflet resection for posterior mitral leaflet prolapse
}

\author{
Amine Mazine, MD, MSc, ${ }^{a}$ Jan O. Friedrich, MD, PhD, ${ }^{b}$ Rashmi Nedadur, MD, ${ }^{a}$ Subodh Verma, MD, PhD, ${ }^{a}$ \\ Maral Ouzounian, MD, PhD, ${ }^{\mathrm{c}}$ Peter Jüni, MD, ${ }^{\mathrm{d}}$ John D. Puskas, MD, ${ }^{\mathrm{e}}$ and Bobby Yanagawa, MD, $\mathrm{PhD}^{\mathrm{a}}$
}

ABSTRACT

Objectives: To compare outcomes of chordal replacement versus leaflet resection techniques for repair of isolated posterior mitral leaflet prolapse.

Methods: We searched MEDLINE and EMBASE databases for studies that compared chordal replacement ("neo-chord" group) versus leaflet resection ("resection" group) techniques for the treatment of posterior mitral leaflet prolapse. Data were extracted by 2 independent investigators and subjected to a meta-analysis using a random-effects model.

Results: One randomized controlled trial (RCT), 1 propensity-matched study, and 6 unadjusted observational studies, with a total of 1926 patients, met our inclusion criteria. Two studies reported only perioperative outcomes; mean follow-up ranged from 1.0 to 5.9 years in the remaining studies. In pooled data from unadjusted observational studies, annuloplasty ring diameter was higher in the neochord group $(+1.5 \mathrm{~mm} ; P=.0003)$, but with high heterogeneity $\left(I^{2}=91 \%\right)$. Based on limited data, postprocedural left ventricular ejection fraction may be greater in the neo-chord group, but this difference reached statistical significance only in the RCT $(+3.4 \% ; P=.03)$, and not in 2 observational studies that reported this outcome $(+2.7 \% ; P=.10)$. There was no difference in recurrent mitral regurgitation at follow-up between the resection and neo-chord groups; however, patients in the neo-chord group had a lower rate of mitral valve reoperation at follow-up in the unadjusted observational studies (incidence rate ratio, 0.22; $P=.0008\left[I^{2}=0 \% ; 4\right.$ studies, 1331 patients $\left.]\right)$.

Conclusions: Chordal replacement may be associated with greater freedom from reoperation and may lead to improved postoperative left ventricular function compared with leaflet resection. However, these conclusions are supported primarily by data from unadjusted observational studies, and high-quality RCTs of

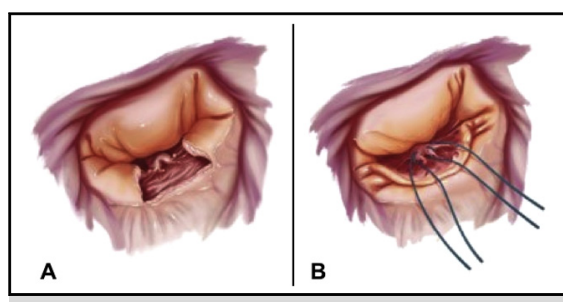

Posterior mitral leaflet repair with leaflet resection (A) versus chordal replacement (B).

\section{Central Message}

Compared with leaflet resection, chordal replacement may be associated with greater freedom from reoperation and improved left ventricular function following repair of posterior mitral prolapse.

\section{Perspective}

The ideal surgical strategy for mitral repair in the setting of isolated posterior prolapse remains unclear. We found that leaflet resection and chordal replacement are associated with similar survival and freedom from recurrent mitral regurgitation. However, chordal replacement may be associated with greater freedom from reoperation and improved postoperative left ventricular function.

See Editorial Commentary page 129. chordal replacement versus leaflet resection are needed. (J Thorac Cardiovasc Surg 2018;155:120-8)

\footnotetext{
From the ${ }^{\mathrm{a}}$ Division of Cardiac Surgery, Department of Surgery, ${ }^{\mathrm{b}}$ Department of Critical Care Medicine, and ${ }^{\mathrm{d}}$ Applied Health Research Centre, Li Ka Shing Knowledge Institute, St Michael's Hospital, and 'Division of Cardiac Surgery, Department of Surgery, Peter Munk Cardiac Centre, Toronto General Hospital, University of Toronto, Toronto, Ontario, Canada; and ${ }^{\mathrm{e} D e p a r t m e n t}$ of Cardiothoracic Surgery, Mount Sinai Saint Luke's, New York, NY.

Received for publication March 26, 2017; revisions received June 26, 2017; accepted for publication July 24, 2017; available ahead of print Sept 26, 2017.

Address for reprints: Bobby Yanagawa, MD, PhD, Division of Cardiac Surgery, Department of Surgery, University of Toronto, St Michael's Hospital, 30 Bond St, 8th Floor, Bond Wing, Toronto, Ontario, Canada M5B 1W8 (E-mail: yanagawab@smh.ca).

$0022-5223 / \$ 36.00$

Copyright (c) 2017 by The American Association for Thoracic Surgery

http://dx.doi.org/10.1016/j.jtcvs.2017.07.078
}

Mitral valve prolapse is common, with a prevalence of $0.6 \%$ to $2.7 \%$ in the general population. ${ }^{1-3}$ Many of these patients will develop severe mitral regurgitation (MR),

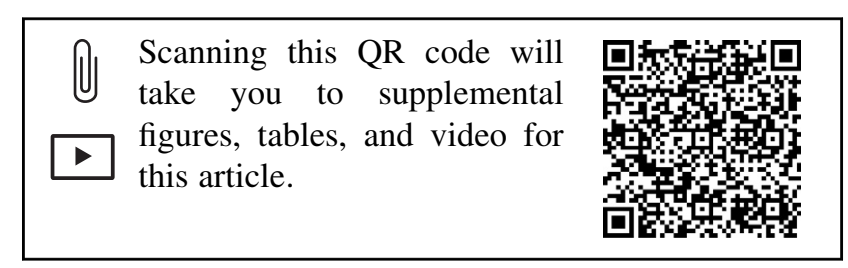




\section{Abbreviations and Acronyms \\ CAMRA $=$ Canadian Mitral Research Alliance \\ CI $=$ confidence interval \\ LVEF $=$ left ventricular ejection fraction \\ MR = mitral regurgitation \\ $\mathrm{RCT}=$ randomized controlled trial \\ $\mathrm{RR} \quad=$ relative risk \\ $\mathrm{SAM}=$ systolic anterior motion}

typically between the fifth and seventh decades of life. Patients with severe symptomatic MR have lower survival compared with age-matched controls. ${ }^{4}$ Even asymptomatic patients are at risk, with one-third developing adverse cardiac events within 5 years of diagnosis. ${ }^{5}$ Mitral valve repair has been shown to improve symptoms and restore survival equivalent to that of age-matched controls. ${ }^{6}$ Furthermore, mitral valve repair is associated with better survival and fewer valve-related complications at follow-up compared with mitral valve replacement. ${ }^{7}$ As a result, mitral valve repair has emerged as the preferred surgical strategy and gold standard treatment for severe mitral regurgitation caused by leaflet prolapse. ${ }^{8}$

The most common leaflet abnormality seen in degenerative mitral regurgitation is isolated prolapse of the posterior leaflet. ${ }^{9}$ This abnormality is repaired primarily with either leaflet resection or leaflet preservation using artificial neochordae. ${ }^{6,9-11}$ Several studies have reported favorable longterm outcomes with both strategies., ${ }^{6,12-15}$ Importantly, despite the fact that mitral valve repair is performed with increasing frequency in North America, ${ }^{16}$ there is equipoise regarding the ideal surgical technique for mitral reconstruction, and thus the decision to use either surgical strategy is based largely on surgeon preference. We conducted the present systematic review and meta-analysis to compare chordal replacement and leaflet resection techniques for the repair of isolated posterior mitral leaflet prolapse.

\section{METHODS}

\section{Data Sources}

On August 9, 2016, we systematically searched Ovid MEDLINE (1996 to 2016 July week 4) and EMBASE Classic (1980 to 2016 week 32) for relevant studies using the following text word search in the title or abstract: "mitral" AND "posterior" AND ("repair" OR "resect*" OR "chord*" OR "neochord*" OR "neo-chord*"), where "*" indicates any other additional letters for the root words in the search strategy. The search strategy is shown in Figure E1. We also searched bibliographies of included studies. We imposed no language restrictions.

\section{Study Selection}

We included all studies comparing any leaflet resection technique to the use of neo-chordae for repair of isolated posterior mitral leaflet prolapse that reported any of the prespecified perioperative or long-term clinical outcomes (ie, all-cause mortality, mitral valve reintervention) or echocardiographic outcomes (ie, residual or recurrent MR, mean mitral valve gradient, effective orifice area, left ventricular ejection fraction (LVEF), presence of systolic anterior motion [SAM]). Studies were excluded if no clinical outcomes were reported or if data were published only as an abstract. Citations were screened in duplicate, and a full text review, also in duplicate, was performed to determine eligibility when either screening reviewer felt that a citation potentially met inclusion criteria. Disagreements regarding inclusion were reconciled via consensus.

\section{Data Extraction and Quality Assessment}

Two reviewers (A.M. and R.N.) independently abstracted data, including details of the publication (ie trial authors, enrolment period, year of publication, study design), inclusion/exclusion criteria, demographics of the enrolled patients, description of the interventions used, and outcome definitions and events. The risks of bias in randomized controlled trials (RCTs) (including blinding of participants, method of sequence generation and allocation concealment, intention-to-treat analysis, early trial stoppage for efficacy before planned enrollment completion, and loss to follow up) and cohort studies (including retrospective vs prospective data collection, concurrent vs historical controls, and comparable baseline characteristics of cases and controls) were formally assessed using the Cochrane Collaboration's Risk of Bias tool for RCTs ${ }^{17}$ and the Newcastle-Ottawa Scale for nonrandomized studies, ${ }^{18}$ respectively. Disagreements were resolved by consensus. This study was conducted in accordance with PRISMA guidelines. ${ }^{19}$

\section{Data Analysis}

All analyses were performed using RevMan version 5.2 (Cochrane Collaboration, Oxford, United Kingdom) and random-effects models, which incorporate between-trial heterogeneity and give wider and more conservative confidence intervals (CIs) when heterogeneity is present. ${ }^{20}$ Statistical heterogeneity among trials was assessed using $I^{2}$, defined as the percentage of total variability across studies attributable to heterogeneity rather than chance, and used published guidelines for low $\left(I^{2}=25 \%\right.$ to $49 \%)$, moderate $\left(I^{2}=50 \%\right.$ to $\left.74 \%\right)$, and high $\left(I^{2}>75 \%\right)$ heterogeneity. ${ }^{21}$ For perioperative outcomes, relative risks (RR) were used to pool binary outcomes and weighted mean differences to pool continuous data. For skewed continuous data, means were assumed to equal medians, and standard deviations were assumed to equal the interquartile range divided by $1.35 .^{22}$ For long-term outcomes with potentially different follow-up between groups, we pooled incidence rate ratios on the logarithmic scale using the generic inverse variance method. When hazard ratios (assumed to be equivalent to incidence rate ratios) were not provided, incidence rate ratios for each study were calculated using Kaplan-Meier survival curve estimates for each group, and the log-rank survival curve $P$ value to estimate the standard error of the logarithm-transformed incidence rate ratio. Individual trial and pooled summary results are reported with $95 \%$ CIs.

Study results were subgrouped by study type: RCT versus propensity score-matched or risk-adjusted observational data versus unmatched/unadjusted observational data. ${ }^{23,24}$ Observational studies that reported both matched or risk-adjusted and unmatched/unadjusted data were included separately for subgroup comparisons. We planned to assess for publication bias using funnel plots if at least 10 trials were identified. ${ }^{17}$

\section{RESULTS}

\section{Characteristics and Quality of Included Studies}

The initial search strategy after de-duplication yielded 2144 citations from MEDLINE and Embase, 20 of which were retrieved for full text review (Figure E1). One $\mathrm{RCT}^{25}$ and 7 observational studies, ${ }^{26-32}$ covering a total of 1926 patients, met our inclusion criteria (Tables E1 and E2). Two studies followed patients only to 30 days or 
TABLE 1. Baseline Demographic Data

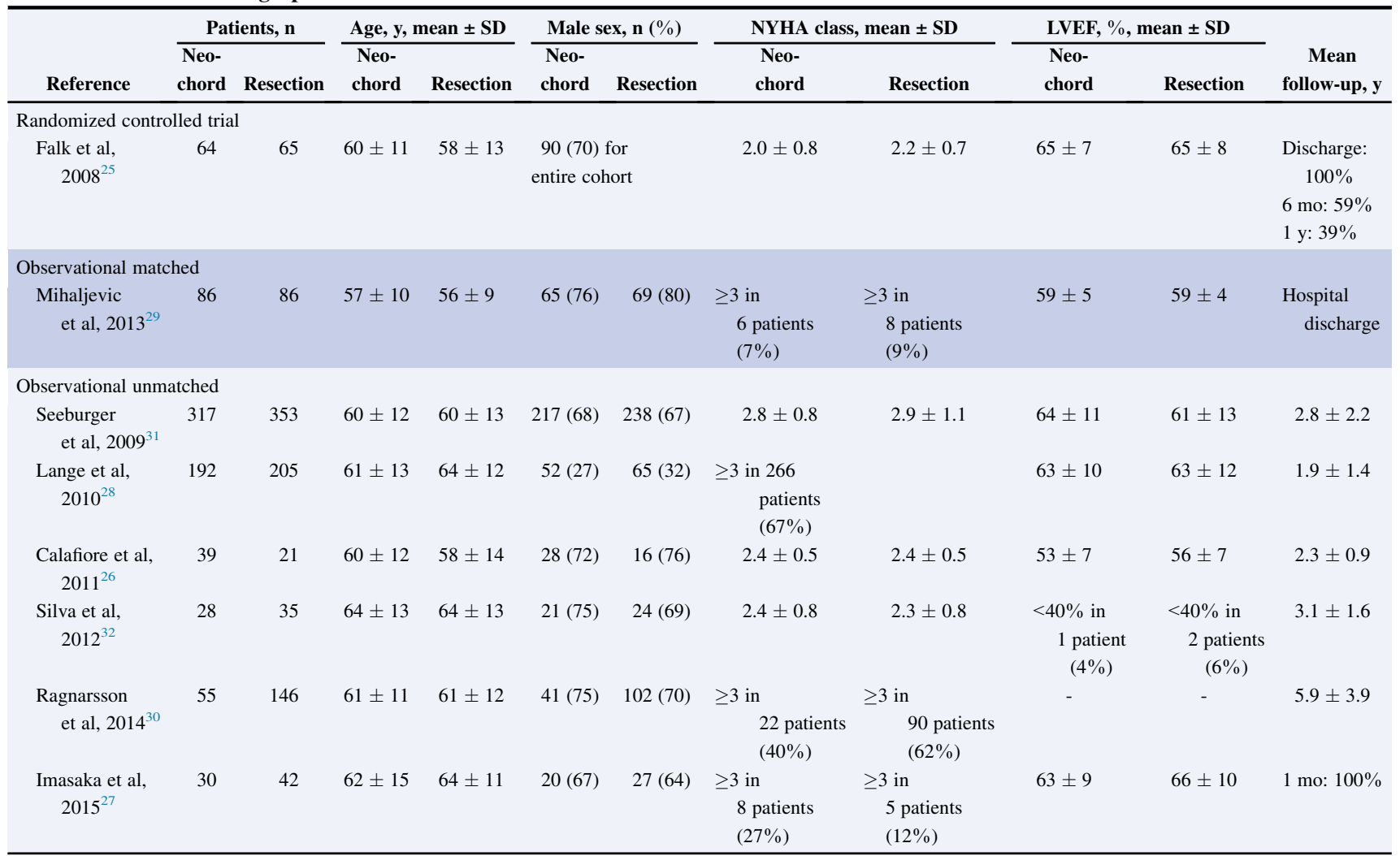

$S D$, Standard deviation; $N Y H A$, New York Heart Association; $L V E F$, left ventricular ejection fraction.

hospital discharge ${ }^{27,29}$; mean follow up ranged from 1.0 to 5.9 years in the remaining studies. The unblinded $\mathrm{RCT}^{25}$ was conducted in 2 centers and used concealed allocation, but excluded 7 of 129 patients who underwent repair using both resection and neo-chordae techniques, and used perprotocol analysis rather than intention-to-treat analysis for the 12 additional patients who crossed over. The 7 included observational studies were retrospective; 1 included 2 centers, ${ }^{30}$ and the other 6 were single-center studies. All observational studies involved comparison with concurrent controls, although in most series the proportion of patients undergoing the neo-chordae procedure increased over time. In all studies, the choice of surgical technique was at the surgeon's discretion, and there typically were baseline differences between the neo-chordae and resection groups (Tables 1 and 2). One of the observational studies also included a matched comparison, ${ }^{29}$ whereas another provided long-term mitral valve reoperation data that were adjusted for baseline differences. ${ }^{31}$ The RCT was considered at high risk of bias owing to lack of blinding, postrandomization exclusions, patient crossover, and lack of intention-to-treat analysis (Table E1). The observational studies scored 6 or 7 out of 9 on the Newcastle-Ottawa Scale, losing points for lack of comparability between groups and short duration of follow-up for some of the studies (Table E3).

\section{Surgical and Perioperative Outcomes}

The propensity-matched observational study demonstrated shorter duration of cardiopulmonary bypass in the neo-chord group, and a similar duration of aortic crossclamp time in the 2 groups (Figures E2 and E3). Conversely, pooled analysis of the remaining observational studies and the single RCT demonstrated no significant differences in cardiopulmonary bypass and aortic cross-clamp times between the 2 groups, with high heterogeneity $\left(I^{2}>90 \%\right)$ among the studies (Figures E2 and E3). Rates of successful mitral valve repair were very high, ranging from $96 \%$ to $100 \%$, and did not differ significantly between the groups (Table 2). Pooling data from the unmatched observational studies, implanted annuloplasty ring diameter was higher in the neo-chord group $(+1.5 \mathrm{~mm} ; 95 \% \mathrm{CI},+0.7$ to $+2.3 \mathrm{~mm} ; P=.0003 ; 6$ studies, 1735 patients), albeit with high heterogeneity $\left(I^{2}=91 \%\right)$. Differences in implanted ring diameters did not reach statistical significance in the single RCT and the matched observational studies (Figure 1). Perioperative mortality was very low and not significantly different between the groups (Figure E4), as 
TABLE 2. Operative Details

\begin{tabular}{|c|c|c|c|c|c|c|}
\hline \multirow[b]{2}{*}{ Reference } & \multicolumn{2}{|c|}{ Surgical approach } & \multicolumn{2}{|c|}{ Technical details } & \multicolumn{2}{|c|}{ Mitral valve repair rate, $\%$} \\
\hline & Neo-chord & Resection & Neo-chord & Resection & Neo-chord & Resection \\
\hline $\begin{array}{l}\text { Randomized controlled trial } \\
\text { Falk et al, } 2008^{28}\end{array}$ & Minithoracotomy & Minithoracotomy & $\begin{array}{l}\text { Premeasured } \\
\text { PTFE neo-chords }\end{array}$ & $\mathrm{QR} \pm$ sliding plasty & 100 & 100 \\
\hline $\begin{array}{l}\text { Observational matched } \\
\text { Mihaljevic et al, } 2013^{29}\end{array}$ & Robotic & Robotic & PTFE neo-chords & $\mathrm{QR} / \mathrm{TR}$ & 100 & 100 \\
\hline $\begin{array}{l}\text { Observational unmatched } \\
\text { Seeburger et al, } 2009^{31}\end{array}$ & Minithoracotomy & Minithoracotomy & $\begin{array}{l}\text { Premeasured } \\
\text { PTFE neo-chords }\end{array}$ & $\mathrm{QR} \pm$ sliding plasty & 100 & 97 \\
\hline Lange et al, $2010^{28}$ & $\begin{array}{l}\text { Sternotomy }(36 \%) \\
\quad \text { Minithoracotomy }(64 \%)\end{array}$ & $\begin{array}{l}\text { Sternotomy }(42 \%) \\
\quad \text { Minithoracotomy }(58 \%)\end{array}$ & PTFE neo-chords & QR & - & - \\
\hline Calafiore et al, $2011^{26}$ & Sternotomy & Sternotomy & PTFE neo-chords & QR & 100 & 100 \\
\hline Silva et al, $2012^{32}$ & Sternotomy & Sternotomy & PTFE neo-chords & QR & 100 & 100 \\
\hline Ragnarsson et al, $2014^{30}$ & $\begin{array}{l}\text { Sternotomy }(74 \%) \\
\quad \text { Minithoracotomy }(26 \%)\end{array}$ & Sternotomy $(100 \%)$ & PTFE neo-chords & $\mathrm{QR} / \mathrm{TR} \pm$ sliding plasty & 96 & 96 \\
\hline Imasaka et al, $2015^{27}$ & Sternotomy & Sternotomy & PTFE neo-chords & QR $(71 \%) / T R(29 \%)$ & 100 & 100 \\
\hline
\end{tabular}

$P T F E$, Polytetrafluoroethylene; $Q R$, quadrangular resection; $T R$, triangular resection.

were rates of perioperative stroke and myocardial infarction (Figures E5 and E6).

The mean postprocedural mitral regurgitation grade was not different between the groups and showed high heterogeneity $\left(I^{2}=78 \%\right)$ (Figure E7). Postprocedural mitral effective orifice area and mean gradient were reported infrequently. Based on data from a single unmatched observational study, the average effective orifice area was significantly larger $(P<.001)$ and the mean mitral gradient was significantly lower $(P=.002)$ in the neo-chord group (Figures E8 and E9). However, the RCT found no significant difference in postprocedural effective orifice area

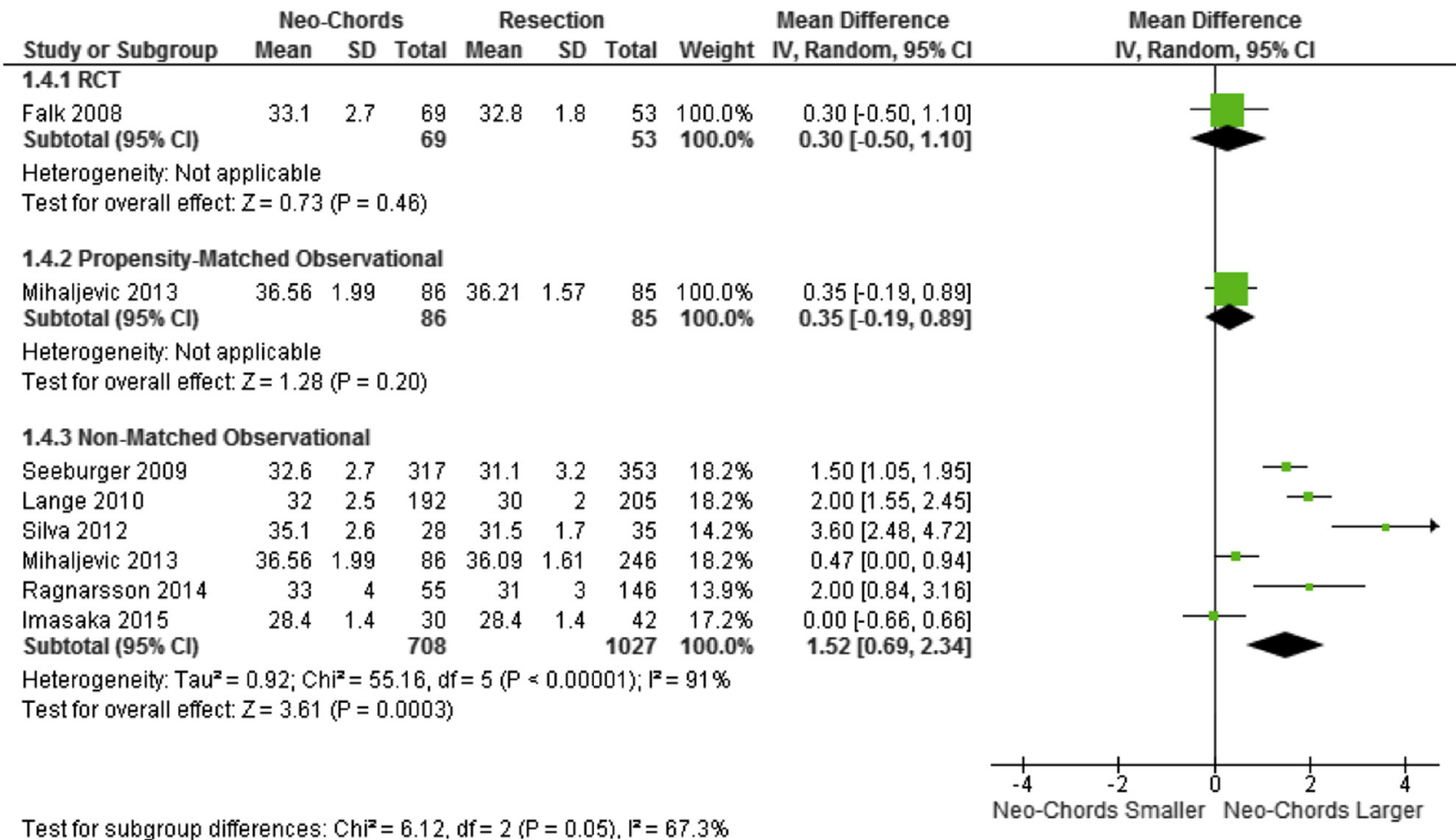

FIGURE 1. Forest plot for implanted annuloplasty ring size diameter. Forest plot comparing chordal replacement versus leaflet resection techniques on implanted annuloplasty ring size diameter (in $\mathrm{mm}$ ). Individual study and pooled mean differences are presented separately for the randomized controlled trial, propensity-matched observational studies, and nonmatched observational studies. The pooled mean differences with $95 \%$ confidence intervals were calculated using random-effects models. $S D$, Standard deviation; $C I$, confidence interval; $R C T$, randomized controlled trial. 


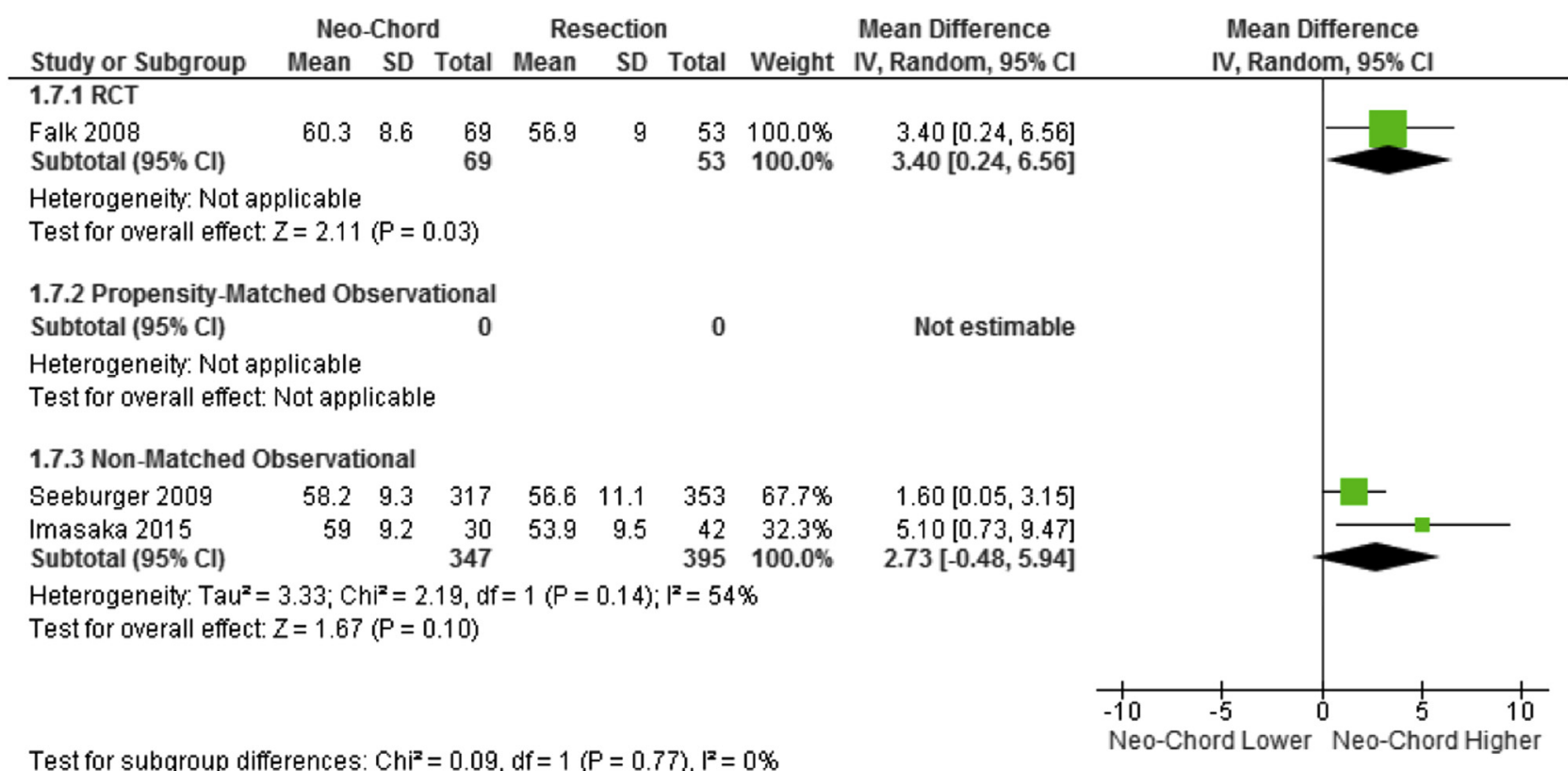

FIGURE 2. Forest plot for postprocedural left ventricular ejection fraction (LVEF). Forest plot comparing chordal replacement versus leaflet resection techniques on postprocedural LVEF (in \%). Individual study and pooled mean differences are presented separately for the randomized controlled trial, propensity-matched observational studies, and nonmatched observational studies. The pooled mean differences with $95 \%$ confidence intervals were calculated using random-effects models. $S D$, Standard deviation; $C I$, confidence interval; $R C T$, randomized controlled trial.

$(P=.34)$, whereas the lower gradients observed in the neochord group were on the cusp of statistical significance $(P=.054)$ (Figures E8 and E9). The incidence of SAM was low and did not differ between the 2 groups (Figure E10). Based on limited data, postprocedural LVEF appeared to be higher in the neo-chord group, but this difference reached statistical significance only in the RCT $(+3.4 \% ; 95 \% \mathrm{CI},+0.2$ to $+6.6 \% ; P=.03)$, not in the 2 observational studies that reported this outcome $(+2.7 \% ; 95 \% \mathrm{CI},-0.5$ to $+5.9 \% ; P=.10)$ (Figure 2$)$.

\section{Long-Term Outcomes}

There was no difference in the rate of recurrent moderate or severe MR at follow-up between the resection and neochord groups (incidence rate ratio, $1.04 ; 95 \% \mathrm{CI}, 0.70$ to $1.55 ; P=.85 ; I^{2}=27 \% ; 3$ unmatched observational studies, 609 patients; mean follow-up, 1.6 to 3.4 years) (Figure 3). However, patients in the neo-chord group had a lower rate of mitral valve reoperation at follow-up in the unadjusted observational studies (RR, 0.22; 95\% CI, 0.09 to $0.54 ; P=.0008 ; I^{2}=0 \% ; 4$ studies, 1331 patients; mean follow-up, 2.0 to 5.9 years) (Figure 4). Similar findings were observed in the observational study that adjusted for the baseline differences between the groups (RR, 0.38; $95 \% \mathrm{CI}, 0.12$ to $1.17 ; P=.09 ; 670$ patients; mean follow-up, 2.8 years), but this did not reach statistical significance (Figure 4). In all 4 studies reporting freedom from reoperation, reintervention was due predominantly to recurrence of MR. Freedom from mitral valve reoperation was not reported in the RCT. The pooled data from observational studies showed no differences in mortality at followup between the groups (RR, $0.27 ; 95 \%$ CI, 0.05 to 1.46 ; $P=.13 ; I^{2}=0 \% ; 4$ studies, 1328 patients; mean followup, 1.2 to 5.9 years). There were no additional deaths at follow-up among perioperative survivors in the single RCT (Figure E11). Mean mitral gradient and LVEF at follow-up were reported infrequently, and were not significantly different between the groups (Figures E12 and E13).

The small number of included studies precluded any meaningful assessment of publication bias, although funnel plots including very small numbers of studies did not suggest the presence of asymmetry.

\section{DISCUSSION}

We performed a systematic review and meta-analysis to compare perioperative and long-term outcomes between chordal replacement and leaflet resection techniques for the repair of isolated posterior mitral leaflet prolapse. The major findings from this study are that both techniques appear to provide similar perioperative outcomes, freedom from recurrent MR, and late survival, and that chordal replacement may allow implantation of larger annuloplasty rings and may be associated with greater freedom from mitral reoperation, although these observations are derived from unmatched observational studies. In addition, chordal replacement may be associated with improved 


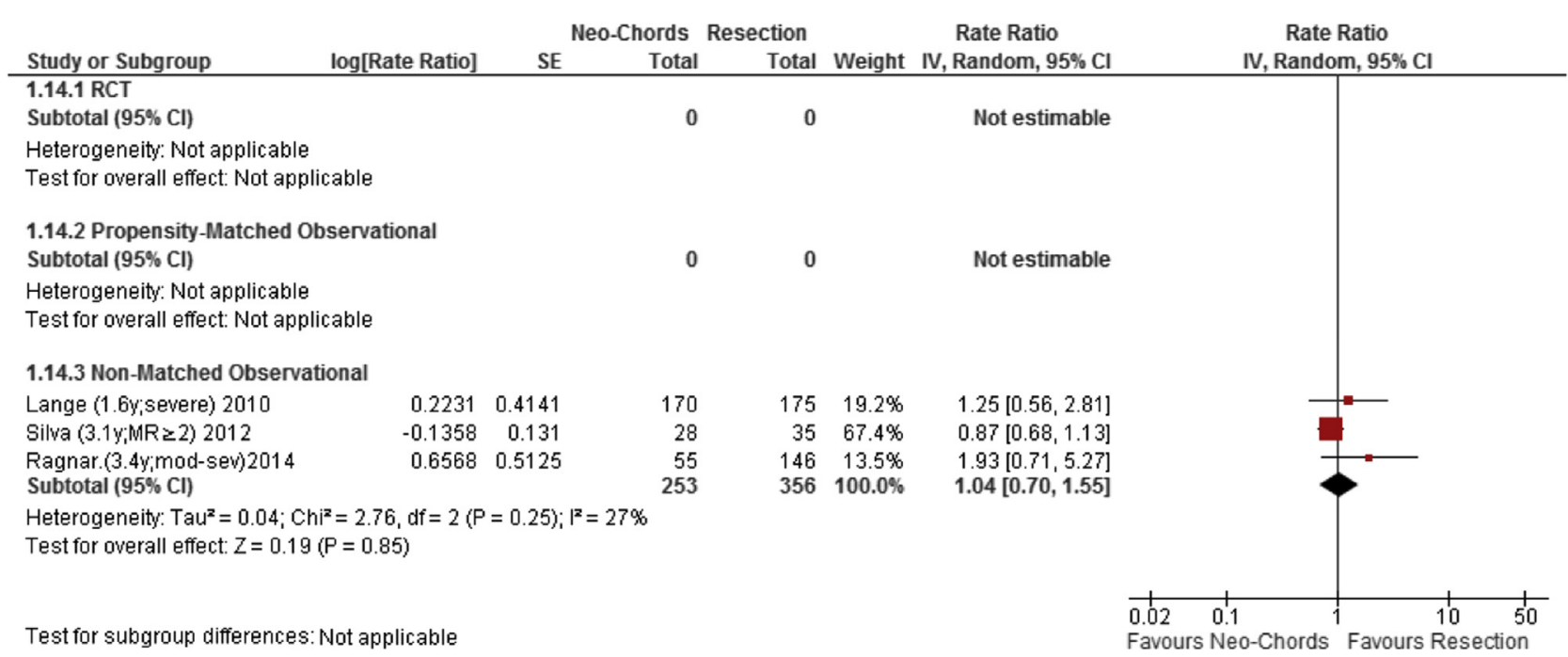

FIGURE 3. Forest plot for freedom from recurrent moderate or severe mitral regurgitation at follow-up. Forest plot comparing chordal replacement versus leaflet resection techniques on freedom from recurrent moderate or severe mitral regurgitation at follow-up. Individual study and pooled incidence rate ratios are presented separately for the randomized controlled trial, propensity-matched observational studies, and nonmatched observational studies. The pooled incidence rate ratios with $95 \%$ confidence intervals were calculated using random-effects models. Mean overall follow up durations are provided in brackets after author name for each study. $S E$, Standard error; $C I$, confidence interval; $R C T$, randomized controlled trial; $M R$, mitral regurgitation.

postoperative left ventricular function. Importantly, this systematic review highlights the lack of high-quality data to inform decisions regarding the optimum surgical technique for mitral reconstruction (Video 1).

Resection of the prolapsed segment and stabilization of the mitral annulus with ring implantation-as described and popularized by Alain Carpentier ${ }^{10}$-has been the conventional technique for the repair of posterior leaflet prolapse for years, and has been associated with excellent long-term outcomes. ${ }^{33}$ This approach may be technically demanding, however. Large resections often require annular plication, which may reduce the overall annular area. Furthermore, finite element studies have suggested excessive stress on the posterior leaflet with the use of resection

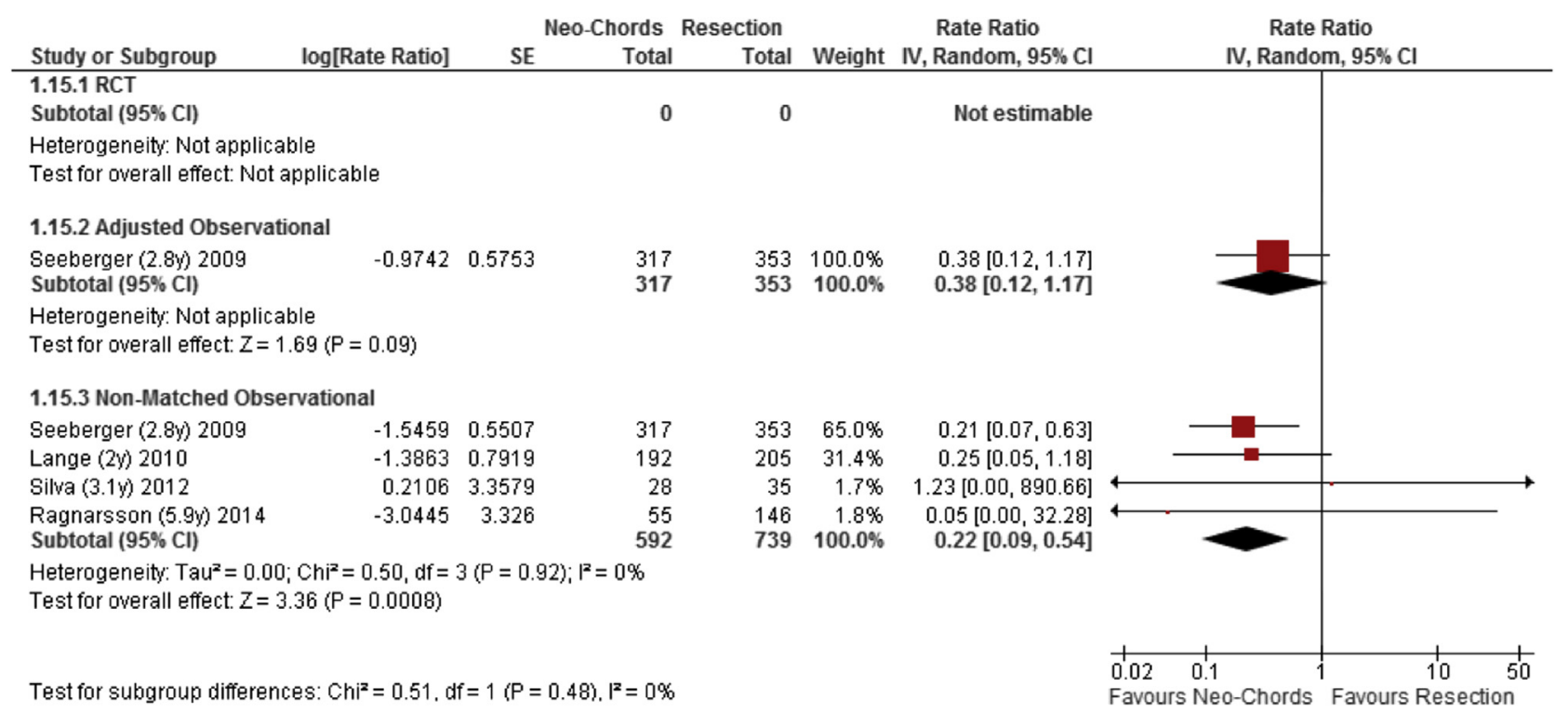

FIGURE 4. Forest plot comparing chordal replacement versus leaflet resection techniques on freedom from mitral valve reoperation at follow-up. Individual study and pooled incidence rate ratios are presented separately for the randomized controlled trial, propensity-matched observational studies, and nonmatched observational studies. The pooled incidence rate ratios with $95 \%$ confidence intervals were calculated using random-effects models. Mean overall follow-up durations are provided in brackets after author name for each study. SE, Standard error; $C I$, confidence interval; $R C T$, randomized controlled trial. 
techniques. ${ }^{34}$ Leaflet preservation techniques-the socalled "respect rather than resect" approach-emerged as an alternative to leaflet resection, which targets correction of leaflet prolapse while preserving leaflet tissue to ensure a larger coaptation surface and a decrease in leaflet stress. $^{35,36}$ This strategy may be technically more straightforward and is more commonly used with minimally invasive approaches. ${ }^{31,37}$

Several studies have reported favorable long-term outcomes with both strategies. ${ }^{6,9,12-15,33}$ However, most of those studies focused on MR recurrence at follow-up as the primary outcome of interest. More recent data have focused on functional mitral stenosis after mitral valve repair. ${ }^{38,39}$ The importance of functional mitral stenosis is being increasingly recognized, with mitral repair now performed in selected asymptomatic patients. ${ }^{8}$ These are often young, active adults who are able to generate large transmitral valve gradients.

Despite revealing no difference in rates of recurrent MR at follow-up, our study does suggest higher rates of reoperation with the use of leaflet resection techniques compared with leaflet preservation with chordal replacement. This finding, coupled with the implantation of smaller annuloplasty rings in the leaflet resection group, raises the question of whether functional mitral stenosis was responsible for the increased rate of reintervention observed in these patients. In the absence of patient-level data, and given the fact that only a few studies have reported mitral effective orifice area and mean gradient at follow-up, this assertion is purely speculative, and the meta-analysis reported herein should be considered as hypothesis-generating. The Canadian Mitral Research Alliance (CAMRA) Randomized Controlled Trial (ClinicalTrials.gov; NCT02552771), a prospective trial comparing the incidence of functional mitral stenosis with resection versus neo-chordal repair, is currently enrolling patients and will shed light on this important issue. ${ }^{40}$

Another interesting finding from this study is the higher postprocedural LVEF in the neo-chord group, which reached statistical significance in the RCT but not in the 2 observational studies that reported this outcome. The rationale for chordal techniques involves "respecting" the normal valvular geometry, which is intimately tied to left ventricular function. David et $\mathrm{al}^{41}$ have previously reported that in resections of the posterior leaflet of the mitral valve $>1.5 \mathrm{~cm}$, there was impaired contractility of the posterior wall of the left ventricle. Similarly, Imasaka et $\mathrm{al}^{27}$ reported superior postoperative left ventricular performance in patients undergoing chordal replacement by virtue of better left ventricular efficiency. Suri et $\mathrm{al}^{42}$ showed that the decrease in LVEF early after mitral valve surgery represents a compensatory mechanism in response to alterations in left ventricular volume and dimensions, rather than left ventricular dysfunction due to

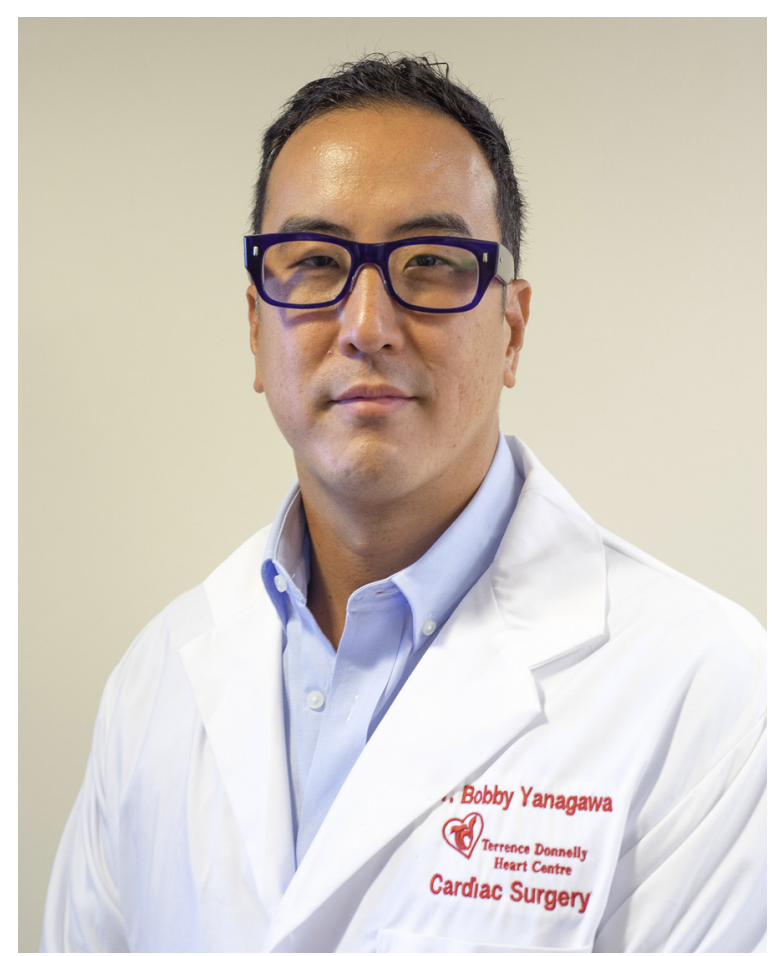

VIDEO 1. Summary of the study. The senior author of this article, Dr Bobby Yanagawa, summarizes the findings of this study and explains their importance and relevance. Video available at: http://www. jtcvsonline.org/article/S0022-5223(17)31774-9/fulltext.

impaired myocardial contractility. ${ }^{42}$ Systolic function after mitral valve surgery is best preserved by maintaining continuity between the mitral apparatus and the left ventricular wall. ${ }^{43}$ Imasaka et $\mathrm{al}^{27}$ postulated that this is one of the mechanisms by which chordal replacement leads to better ventricular function, because this technique does not involve any disruption of the ventriculoannular continuity.

The comparative incidence of postoperative SAM in resection and nonrejection techniques is controversial. SAM can occur with both insufficient posterior leaflet resection and the use of excessively long posterior leaflet neo-chords, which displace the coaptation line toward the left ventricular outflow tract. ${ }^{44,45}$ In the present metaanalysis, the incidence of postoperative SAM was low and did not differ between the 2 groups, suggesting that with careful attention, the risk can be largely mitigated using either technique.

Mitral valve repair is a dynamic field, as evidenced by the introduction of several new repair techniques over the last several years. ${ }^{46}$ Beyond the approaches that form the focus of this study, a number of novel techniques have been reported, including butterfly resection ${ }^{47}$ foldoplasty, ${ }^{48}$ leaflet remodeling, ${ }^{49}$ and chordal transfer. ${ }^{13}$ Many such techniques were developed to facilitate minimally invasive approaches. It is critical that mitral surgeons can use several different 
techniques individualized to the quality and quantity of mitral tissue, as well as each patient's specific dysfunction and lesions. Further studies are needed to determine the subgroup of patients that stands to gain the most from each technique.

\section{Study Strengths and Limitations}

To our knowledge, this is the first systematic review and meta-analysis to compare leaflet resection versus chordal replacement techniques for the repair of isolated posterior mitral leaflet prolapse. The strength of this review is the use of rigorous methodology, including a reproducible and comprehensive literature search, clearly defined inclusion criteria, duplicate citation review, data abstraction, and quality assessment of individual studies. Our systematic review highlights the small number of studies, and the small numbers of enrolled patients per study, examining this question. In contrast to the abundance of case series describing medium- and long-term outcomes of mitral valve repair using either resection or nonresection techniques, there is a paucity of comparative data and only a single RCT directly comparing the 2 approaches. Of note, this RCT enrolled less than one-half of all eligible patients during the study period, raising questions about a potential selection bias. Furthermore, there was significant heterogeneity among the included studies regarding outcomes reported, patient baseline characteristics, and surgical approach used (ie, standard, minithoracotomy, or robotic). Many of the studies compared cohorts that were not entirely contemporaneous (given that use of the neo-chordae technique typically increased over time), raising questions about a potential learning curve effect. In addition, essentially all the observational studies included in this meta-analysis had baseline differences between the groups and/or differences in criteria for undergoing neo-chordae repair versus resection, and small differences in valve anatomy and function-which are unlikely to be recorded in retrospective unmatched studies-could have significantly affected the results. As a result of these limitations, it is difficult to arrive at definitive conclusions from the limited data, and findings from this study should be regarded as hypothesisgenerating. In addition, it is unclear how closely outcomes within each study might have been related to individual surgeons' experience and level of comfort with each of the 2 techniques. Furthermore, most studies included in this analysis focused on survival, reintervention, and MR recurrence, with few studies reporting echocardiographic outcomes, such as effective orifice area and mitral gradient.

\section{CONCLUSIONS}

Chordal replacement and leaflet resection offer excellent outcomes in the repair of posterior mitral valve prolapse with respect to MR recurrence and late survival. However, data from primarily observational studies suggest that chordal replacement may be associated with greater freedom from reoperation. In addition, chordal replacement may lead to improved postoperative left ventricular function. High-quality, long-term prospective trials of chordal replacement versus leaflet resection for posterior leaflet prolapse are needed.

\section{Conflict of Interest Statement}

Authors have nothing to disclose with regard to commercial support.

\section{References}

1. Flack JM, Kvasnicka JH, Gardin JM, Gidding SS, Manolio TA, Jacobs DR Jr. Anthropometric and physiologic correlates of mitral valve prolapse in a biethnic cohort of young adults: the CARDIA study. Am Heart J. 1999;138(3 Pt 1): 486-92.

2. Freed LA, Levy D, Levine RA, Larson MG, Evans JC, Fuller DL, et al. Prevalence and clinical outcome of mitral-valve prolapse. N Engl J Med. 1999; 341:1-7.

3. Theal M, Sleik K, Anand S, Yi Q, Yusuf S, Lonn E. Prevalence of mitral valve prolapse in ethnic groups. Can J Cardiol. 2004;20:511-5.

4. Ling LH, Enriquez-Sarano M, Seward JB, Tajik AJ, Schaff HV, Bailey KR, et al. Clinical outcome of mitral regurgitation due to flail leaflet. N Engl J Med. 1996; 335:1417-23.

5. Enriquez-Sarano M, Avierinos JF, Messika-Zeitoun D, Detaint D, Capps M, Nkomo V, et al. Quantitative determinants of the outcome of asymptomatic mitral regurgitation. $N$ Engl J Med. 2005;352:875-83.

6. Braunberger E, Deloche A, Berrebi A, Abdallah F, Celestin JA, Meimoun P, et al. Very long-term results (more than 20 years) of valve repair with Carpentier's techniques in nonrheumatic mitral valve insufficiency. Circulation. 2001; 104(12 Suppl 1):I8-11.

7. Lazam S, Vanoverschelde JL, Tribouilloy C, Grigioni F, Suri RM, Avierinos JF, et al. Twenty-year outcome after mitral repair versus replacement for severe degenerative mitral regurgitation: analysis of a large, prospective, multicenter international egistry. Circulation. 2017;135:410-22.

8. Nishimura RA, Otto CM, Bonow RO, Carabello BA, Erwin JP III, Guyton RA, et al. 2014 AHA/ACC guideline for the management of patients with valvular heart disease: a report of the American College of Cardiology/American Heart Association Task Force on Practice Guidelines. J Thorac Cardiovasc Surg. 2014;148:e1-132.

9. Verma S, Mesana TG. Mitral-valve repair for mitral-valve prolapse. $N$ Engl $J$ Med. 2009;361:2261-9.

10. Carpentier A. Cardiac valve surgery-the "French correction" J Thorac Cardiovasc Surg. 1983;86:323-37.

11. Filsoufi F, Carpentier A. Principles of reconstructive surgery in degenerative mitral valve disease. Semin Thorac Cardiovasc Surg. 2007;19:103-10.

12. Castillo JG, Anyanwu AC, Fuster V, Adams DH. A near 100\% repair rate for mitral valve prolapse is achievable in a reference center: implications for future guidelines. J Thorac Cardiovasc Surg. 2012;144:308-12.

13. Chan V, Ruel M, Chaudry S, Lambert S, Mesana TG. Clinical and echocardiographic outcomes after repair of mitral valve bileaflet prolapse due to myxomatous disease. J Thorac Cardiovasc Surg. 2012;143(4 Suppl):S8-11.

14. Chan V, Ruel M, Hynes M, Chaudry S, Mesana TG. Impact of mitral annular calcification on early and late outcomes following mitral valve repair of myxomatous degeneration. Interact Cardiovasc Thorac Surg. 2013;17: $120-5$.

15. David TE, Armstrong S, McCrindle BW, Manlhiot C. Late outcomes of mitral valve repair for mitral regurgitation due to degenerative disease. Circulation 2013; 127:1485-92.

16. Gammie JS, Sheng S, Griffith BP, Peterson ED, Rankin JS, O'Brien SM, et al Trends in mitral valve surgery in the United States: results from the Society of Thoracic Surgeons Adult Cardiac Surgery Database. Ann Thorac Surg. 2009; 87:1431-7; discussion 1437-9.

17. Higgins JPT, Green S, eds. Cochrane Handbook for Systematic Reviews of Interventions, version 5.1.0 (updated March 2011). The Cochrane 
Collaboration; 2011. Available at: http://www.handbook.cochrane.org/. Accessed June 18, 2017.

18. Wells GA, Shea B, O'Connell D, Peterson J, Welch V, Losos M, et al. The Newcastle-Ottawa Scale (NOS) for assessing the quality of nonrandomised studies in meta-analyses. Available at: http://www.ohri.ca/programs/clinical_ epidemiology/oxford.htm. Accessed June 18, 2017.

19. Moher D, Liberati A, Tetzlaff J, Altman DG. Preferred reporting items for systematic reviews and meta-analyses: the PRISMA statement. PLoS Med. 2009; 6:e1000097.

20. DerSimonian R, Laird N. Meta-analysis in clinical trials. Control Clin Trials. 1986; $7: 177-88$.

21. Higgins JP, Thompson SG, Deeks JJ, Altman DG. Measuring inconsistency in meta-analyses. BMJ. 2003;327:557-60.

22. Medians and interquartile ranges. In: Higgins JPT, Green S, eds. Cochrane Handbook for Systematic Reviews of Interventions, version 5.1.0 (updated March 2011). The Cochrane Collaboration; 2011. Available at: http://handbook. cochrane.org/. Accessed January 16, 2017.

23. Yanagawa B, Verma S, Jüni P, Tam DY, Mazine A, Puskas JD, et al. A systematic review and meta-analysis of in situ versus composite bilateral internal thoracic artery grafting. J Thorac Cardiovasc Surg. 2017;153: 1108-16.e16.

24. Yanagawa B, Verma S, Mazine A, Tam DY, Jüni P, Puskas JD, et al. Impact of total arterial revascularization on long term survival: a systematic review and meta-analysis of 130,305 patients. Int J Cardiol. 2017;233:29-36.

25. Falk V, Seeburger J, Czesla M, Borger MA, Willige J, Kuntze T, et al. How does the use of polytetrafluoroethylene neochordae for posterior mitral valve prolapse (loop technique) compare with leaflet resection? A prospective randomized trial. J Thorac Cardiovasc Surg. 2008;136:1205; discussion 1205-6.

26. Calafiore AM, Di Mauro M, Iacò AL, Varone E, Romeo A, Mangiafico S, et al. Resecting and nonresecting techniques for posterior mitral leaflet prolapse. J Card Surg. 2011;26:119-23.

27. Imasaka K, Tayama E, Tomita Y. Left ventricular performance early after repair for posterior mitral leaflet prolapse: chordal replacement versus leaflet resection. J Thorac Cardiovasc Surg. 2015;150:538-45.

28. Lange R, Guenther T, Noebauer C, Kiefer B, Eichinger W, Voss B, et al Chordal replacement versus quadrangular resection for repair of isolated posterior mitral leaflet prolapse. Ann Thorac Surg. 2010;89:1163-70; discussion 1170 .

29. Mihaljevic T, Pattakos G, Gillinov AM, Bajwa G, Planinc M, Williams SJ, et al. Robotic posterior mitral leaflet repair: neochordal versus resectional techniques. Ann Thorac Surg. 2013;95:787-94.

30. Ragnarsson S, Sjögren J, Sanchez R, Wierup P, Nozohoor S. Polytetrafluoroethylene neochordae is noninferior to leaflet resection in repair of isolated posterior mitral leaflet prolapse: a multicentre study. Interact Cardiovasc Thorac Surg. 2014; 19:577-83.

31. Seeburger J, Falk V, Borger MA, Passage J, Walther T, Doll N, et al. Chordae replacement versus resection for repair of isolated posterior mitral leaflet prolapse: à ègalité. Ann Thorac Surg. 2009;87:1715-20.

32. Silva J, Blanco E, Maroto LC, Cobiella J, Carnero M, Villagrán E, et al. Resección cuadrangular frente al uso de neocuerdas en la reparación del velo posterior mitral. Resultados clínicos y ecocardiográficos. [Quadrangular resection versus chordae replacement for posterior mitral leaflet repair: clinical and echocardiographic result.]. Cir Cardiov. 2012;19:39-46 [in Spanish].

33. Mohty D, Orszulak TA, Schaff HV, Avierinos JF, Tajik JA, Enriquez-Sarano M. Very long-term survival and durability of mitral valve repair for mitral valve prolapse. Circulation. 2001;104(12 Suppl 1):I1-7.
34. Morgan AE, Pantoja JL, Grossi EA, Ge L, Weinsaft JW, Ratcliffe MB. Neochord placement versus triangular resection in mitral valve repair: a finite element model. J Surg Res. 2016;206:98-105.

35. David TE, Bos J, Rakowski H. Mitral valve repair by replacement of chordae tendineae with polytetrafluoroethylene sutures. J Thorac Cardiovasc Surg. 1991; 101:495-501.

36. von Oppell UO, Mohr FW. Chordal replacement for both minimally invasive and conventional mitral valve surgery using premeasured Gore-Tex loops. Ann Thorac Surg. 2000;70:2166-8.

37. Kuntze T, Borger MA, Falk V, Seeburger J, Girdauskas E, Doll N, et al. Early and mid-term results of mitral valve repair using premeasured Gore-Tex loops ('loop technique'). Eur J Cardiothorac Surg. 2008;33:566-72.

38. Chan KL, Chen SY, Chan V, Hay K, Mesana T, Lam BK. Functional significance of elevated mitral gradients after repair for degenerative mitral regurgitation. Circ Cardiovasc Imaging. 2013;6:1041-7.

39. Mesana TG, Lam BK, Chan V, Chen K, Ruel M, Chan K. Clinical evaluation of functional mitral stenosis after mitral valve repair for degenerative disease: potential affect on surgical strategy. J Thorac Cardiovasc Surg. 2013;146: 1418-23; discussion 1423-5.

40. Chan V, Chu MWA, Leong-Poi H, Latter DA, Hall J, Thorpe KE, et al. Randomised trial of mitral valve repair with leaflet resection versus leaflet preservation on functional mitral stenosis (The CAMRA CardioLink-2 Trial). BMJ Open. 2017;7:e015032.

41. David TE, Omran A, Armstrong S, Sun Z, Ivanov J. Long-term results of mitral valve repair for myxomatous disease with and without chordal replacement with expanded polytetrafluoroethylene sutures. J Thorac Cardiovasc Surg. 1998;115: 1279-85; discussion 1285-6.

42. Suri RM, Schaff HV, Dearani JA, Sundt TM III, Daly RC, Mullany CJ, et al. Determinants of early decline in ejection fraction after surgical correction of mitral regurgitation. J Thorac Cardiovasc Surg. 2008;136:442-7.

43. Goldfine H, Aurigemma GP, Zile MR, Gaasch WH. Left ventricular length-forceshortening relations before and after surgical correction of chronic mitral regurgitation. J Am Coll Cardiol. 1998;31:180-5.

44. Kuperstein R, Spiegelstein D, Rotem G, Stein M, Kogan A, Sternik L, et al. Late clinical outcome of transient intraoperative systolic anterior motion post mitral valve repair. J Thorac Cardiovasc Surg. 2015;149:471-6.

45. Varghese R, Itagaki S, Anyanwu AC, Trigo P, Fischer G, Adams DH. Predicting systolic anterior motion after mitral valve reconstruction: using intraoperative transoesophageal echocardiography to identify those at greatest risk. Eur J Cardiothorac Surg. 2014;45:132-7; discussion 137-8.

46. Woo YJ, Goldstone AB. The contemporary evolution of mitral valve surgery. $J$ Thorac Cardiovasc Surg. 2016;151:7-9.

47. Asai T, Kinoshita T, Suzuki T, Shiraishi S, Koike M. Early and follow-up results of butterfly resection of prolapsed posterior leaflet in 76 consecutive patients. $J$ Thorac Cardiovasc Surg. 2015;149:1296-300.

48. Cevasco M, Myers PO, Elbardissi AW, Cohn LH. Foldoplasty: a new and simplified technique for mitral valve repair that produces excellent medium-term outcomes. Ann Thorac Surg. 2011;92:1634-7; discussion 1637-8.

49. MacArthur JW Jr, Cohen JE, Goldstone AB, Fairman AS, Edwards BB, Hornick MA, et al. Nonresectional single-suture leaflet remodeling for degenerative mitral regurgitation facilitates minimally invasive mitral valve repair. Ann Thorac Surg. 2013;96:1603-6.

Key Words: mitral valve repair, posterior leaflet prolapse, leaflet resection, chordal replacement, meta-analysis 


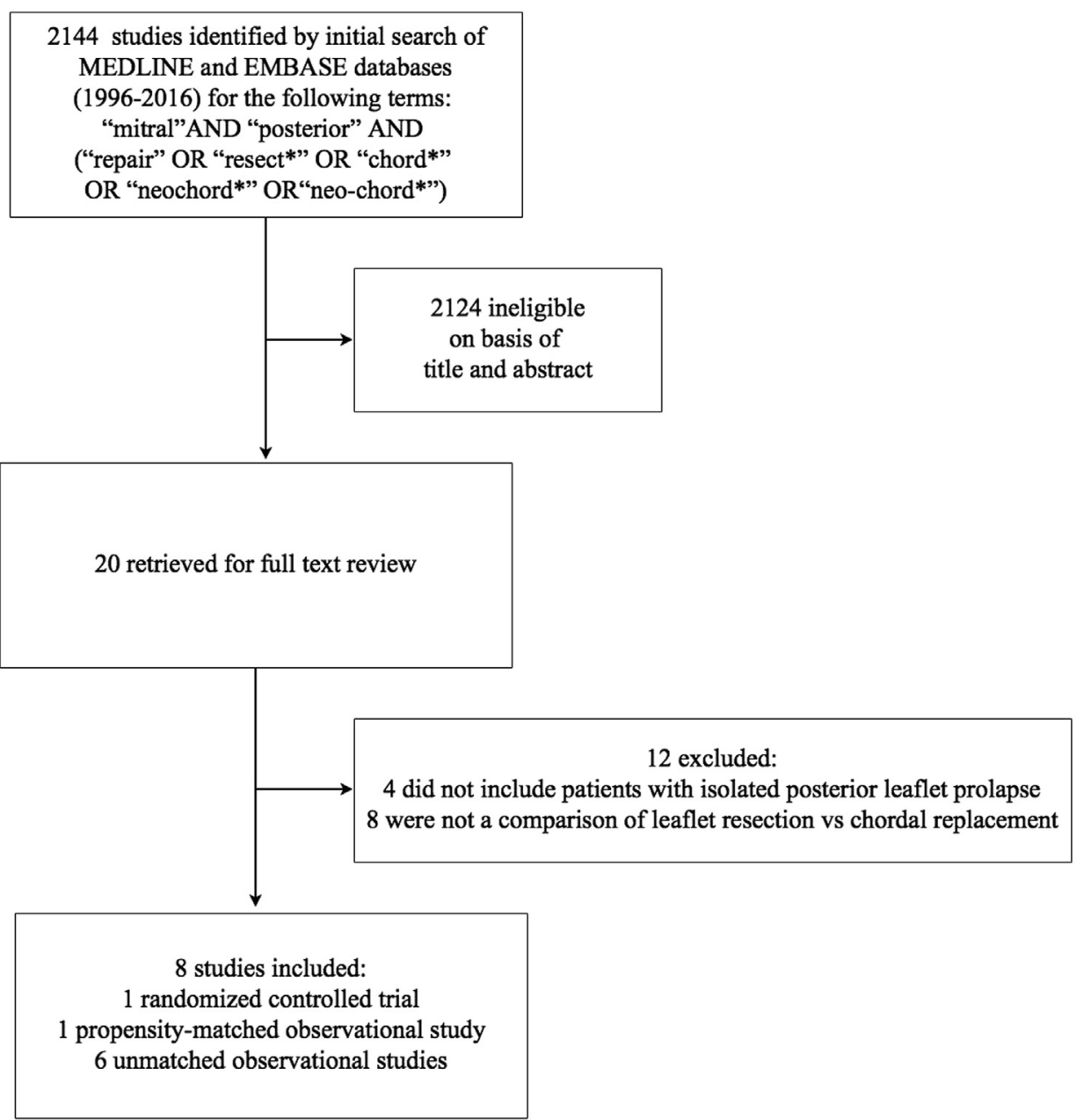

FIGURE E1. Search strategy and study flowchart. Flow chart for the systematic review and meta-analysis showing the search strategy, and the number of studies retained and number of studies excluded with reason for exclusion at each stage of the study selection process. 


\begin{tabular}{|c|c|c|c|c|c|c|c|c|c|}
\hline \multirow{3}{*}{$\frac{\text { Study or Subgroup }}{1.2 .1 \text { RCT }}$} & \multicolumn{3}{|c|}{ Neo-Chords } & \multicolumn{3}{|c|}{ Resection } & \multirow[b]{2}{*}{ Weight } & \multirow{2}{*}{$\begin{array}{l}\text { Mean Difference } \\
\mathrm{IV}, \text { Random, } 95 \% \mathrm{Cl}\end{array}$} & \multirow{2}{*}{$\begin{array}{l}\text { Mean Difference } \\
\text { IV, Random, } 95 \% \mathrm{Cl}\end{array}$} \\
\hline & Mean & SD & Total & Mean & SD & Total & & & \\
\hline & & & & & & & & & \\
\hline $\begin{array}{l}\text { Falk } 2008 \\
\text { Subtotal }(95 \% \mathrm{Cl})\end{array}$ & 137 & 42 & $\begin{array}{l}69 \\
69\end{array}$ & 129 & 32 & $\begin{array}{l}53 \\
53\end{array}$ & $\begin{array}{l}100.0 \% \\
100.0 \%\end{array}$ & $\begin{array}{l}8.00[-5.13,21.13] \\
8.00[-5.13,21.13]\end{array}$ & \\
\hline \multicolumn{9}{|c|}{ Heterogeneity: Not applicable } & Test for overall effect: $Z=1.19(P=0.23)$ \\
\hline \multicolumn{10}{|c|}{ 1.2.2 Propensity-Matched Observational } \\
\hline $\begin{array}{l}\text { Mihaljevic } 2013 \\
\text { Subtotal }(95 \% \mathrm{Cl})\end{array}$ & 106 & 22 & $\begin{array}{l}86 \\
86\end{array}$ & 118 & 35 & $\begin{array}{l}86 \\
86\end{array}$ & $\begin{array}{l}100.0 \% \\
100.0 \%\end{array}$ & $\begin{array}{l}-12.00[-20.74,-3.26] \\
-12.00[-20.74,-3.26]\end{array}$ & \\
\hline \multicolumn{10}{|c|}{$\begin{array}{l}\text { Heterogeneity: Not applicable } \\
\text { Test for overall effect: } Z=2.69(P=0.007)\end{array}$} \\
\hline \multicolumn{10}{|c|}{ 1.2.3 Non-Matched Observational } \\
\hline Seeburger 2009 & 124 & 37 & 317 & 113 & 35 & 353 & $18.0 \%$ & $11.00[5.53,16.47]$ & \\
\hline Lange 2010 & 108 & 32 & 144 & 110 & 37 & 149 & $17.4 \%$ & $-2.00[-9.91,5.91]$ & \\
\hline Silva 2012 & 88.5 & 20.74 & 28 & 58 & 28.89 & 35 & $15.9 \%$ & $30.50[18.23,42.77]$ & \\
\hline Mihaljevic 2013 & 106 & 22 & 86 & 119 & 34 & 248 & $17.8 \%$ & $-13.00[-19.29,-6.71]$ & \\
\hline Ragnarsson 2014 & 110 & 37 & 55 & 124 & 30 & 146 & $16.4 \%$ & $-14.00[-24.92,-3.08]$ & \\
\hline $\begin{array}{l}\text { Imasaka } 2015 \\
\text { Subtotal }(95 \% \mathrm{Cl})\end{array}$ & 182 & 31 & $\begin{array}{r}30 \\
660\end{array}$ & 164 & 37 & $\begin{array}{r}42 \\
973\end{array}$ & $\begin{array}{r}14.5 \% \\
100.0 \%\end{array}$ & $\begin{array}{l}18.00[2.24,33.76] \\
4.47[-8.21,17.16]\end{array}$ & \\
\hline \multicolumn{10}{|c|}{$\begin{array}{l}\text { Heterogeneity: } \text { Tau }^{2}=224.56 ; \mathrm{Chi}^{2}=66.15, \mathrm{df}=5(\mathrm{P}=0.00001) ;\left.\right|^{2}=92 \% \\
\text { Test for overall effect: } Z=0.69(P=0.49)\end{array}$} \\
\hline
\end{tabular}

FIGURE E2. Forest plot comparing chordal replacement versus leaflet resection techniques on duration of cardiopulmonary bypass (in minutes). Individual study and pooled mean differences are presented separately for the randomized controlled trial, propensity-matched observational studies, and nonmatched observational studies. The pooled mean differences with $95 \%$ confidence intervals were calculated using random-effects models. SD, Standard deviation; $C I$, confidence interval; $R C T$, randomized controlled trial.

\begin{tabular}{|c|c|c|c|c|c|c|c|c|c|}
\hline \multirow{2}{*}{ Study or Subgroup } & \multicolumn{3}{|c|}{ Neo-Chords } & \multicolumn{3}{|c|}{ Resection } & \multirow[b]{2}{*}{ Weight } & \multirow{2}{*}{$\begin{array}{l}\text { Mean Difference } \\
\text { IV, Random, } 95 \% \mathrm{Cl}\end{array}$} & \multirow{2}{*}{$\begin{array}{l}\text { Mean Difference } \\
\text { IV, Random, } 95 \% \mathrm{Cl}\end{array}$} \\
\hline & Mean & SD & Total & Mean & SD & Total & & & \\
\hline 1.3.1 RCT & & & & & & & & & \\
\hline $\begin{array}{l}\text { Falk } 2008 \\
\text { Subtotal }(95 \% \mathrm{Cl})\end{array}$ & 84.1 & 25.1 & $\begin{array}{l}69 \\
69\end{array}$ & 78.6 & 27.7 & $\begin{array}{l}53 \\
53\end{array}$ & $\begin{array}{l}100.0 \% \\
100.0 \%\end{array}$ & $\begin{array}{l}5.50[-4.02,15.02] \\
5.50[-4.02,15.02]\end{array}$ & \\
\hline \multicolumn{10}{|c|}{ Heterogeneity: Not applicable } \\
\hline \multicolumn{10}{|c|}{ Test for overall effect: $Z=1.13(P=0.26)$} \\
\hline \multicolumn{10}{|c|}{ 1.3.2 Propensity-Matched Observational } \\
\hline $\begin{array}{l}\text { Mihaljevic } 2013 \\
\text { Subtotal }(95 \% \mathrm{Cl})\end{array}$ & 79 & 16 & $\begin{array}{l}86 \\
86\end{array}$ & 85 & 31 & $\begin{array}{l}86 \\
86\end{array}$ & $\begin{array}{l}100.0 \% \\
100.0 \%\end{array}$ & $\begin{array}{l}-6.00[-13.37,1.37] \\
-6.00[-13.37,1.37]\end{array}$ & \\
\hline \multicolumn{10}{|c|}{ Heterogeneity: Not applicable } \\
\hline \multicolumn{10}{|c|}{ Test for overall effect: $Z=1.59(P=0.11)$} \\
\hline \multicolumn{10}{|c|}{ 1.3.3 Non-Matched Observational } \\
\hline Seeburger 2009 & 78 & 27 & 317 & 65 & 29 & 353 & $18.2 \%$ & $13.00[8.76,17.24]$ & -- \\
\hline Lange 2010 & 78 & 22 & 144 & 80 & 23 & 149 & $17.9 \%$ & $-2.00[-7.15,3.15]$ & \\
\hline Silva 2012 & 69.5 & 18.52 & 28 & 48 & 22.96 & 35 & $15.6 \%$ & $21.50[11.26,31.74]$ & \\
\hline Mihaljevic 2013 & 79 & 16 & 86 & 86 & 28 & 248 & $18.0 \%$ & $-7.00[-11.86,-2.14]$ & 一- \\
\hline Ragnarsson 2014 & 80 & 28 & 55 & 91 & 24 & 146 & $16.5 \%$ & $-11.00[-19.36,-2.64]$ & \\
\hline $\begin{array}{l}\text { Imasaka } 2015 \\
\text { Subtotal }(95 \% \mathrm{Cl})\end{array}$ & 128 & 26 & $\begin{array}{r}30 \\
660\end{array}$ & 117 & 33 & $\begin{array}{r}42 \\
973\end{array}$ & $\begin{array}{r}13.7 \% \\
100.0 \%\end{array}$ & $\begin{array}{r}11.00[-2.64,24.64] \\
3.78[-5.83,13.39]\end{array}$ & \\
\hline \multicolumn{10}{|c|}{$\begin{array}{l}\text { Heterogeneity: } \text { Tau }^{2}=127.09 ; \mathrm{Chi}^{2}=65.86, \mathrm{df}=5(\mathrm{P}<0.00001) ; \mathrm{I}^{2}=92 \% \\
\text { Test for overall effect: } Z=0.77(\mathrm{P}=0.44)\end{array}$} \\
\hline
\end{tabular}

FIGURE E3. Forest plot comparing chordal replacement versus leaflet resection techniques on duration of aortic cross-clamping (in minutes). Individual study and pooled mean differences are presented separately for the randomized controlled trial, propensity-matched observational studies, and nonmatched observational studies. The pooled mean differences with $95 \%$ confidence intervals were calculated using random-effects models. $S D$, Standard deviation; $C I$, confidence interval; $R C T$, randomized controlled trial. 


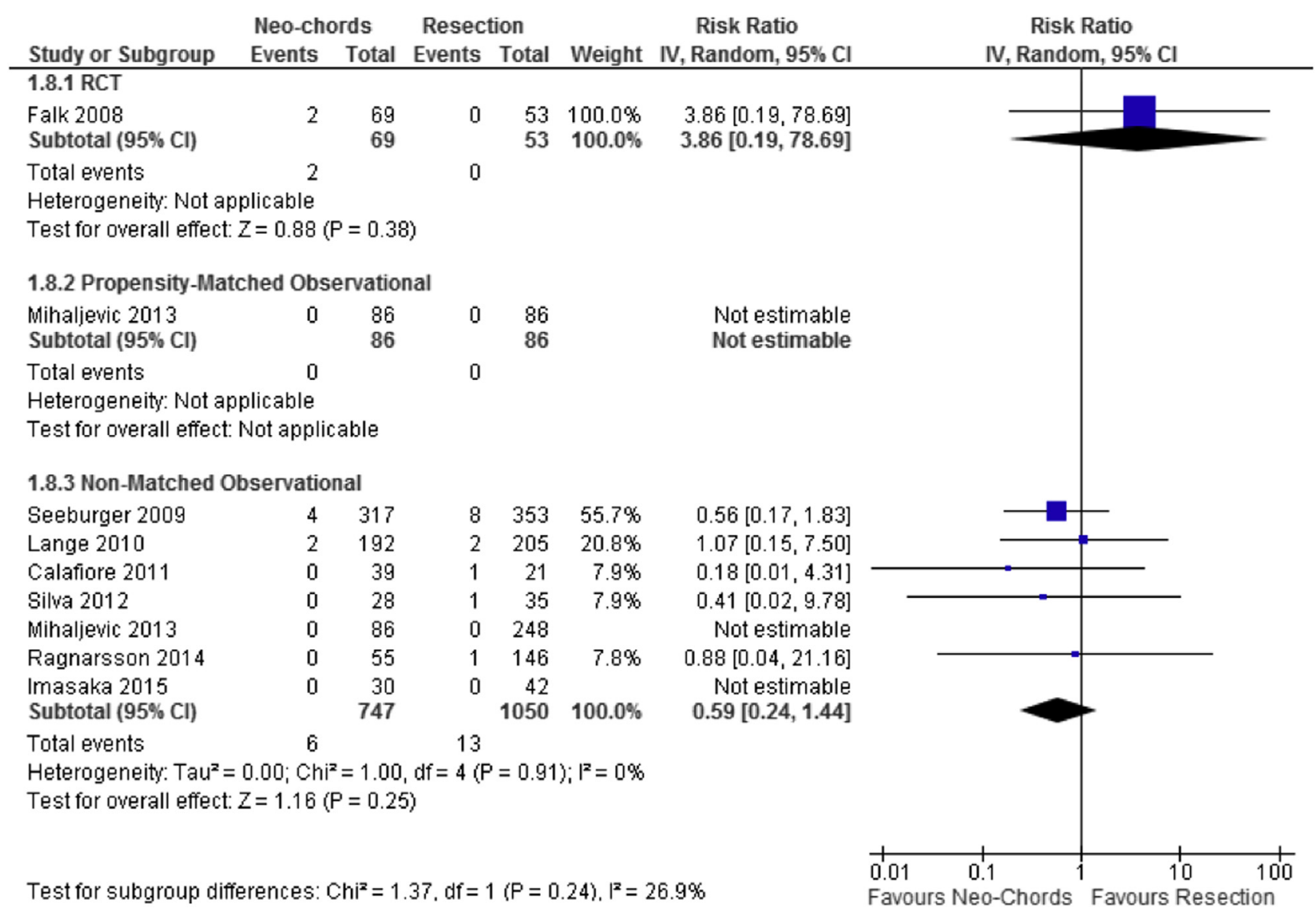

FIGURE E4. Forest plot comparing chordal replacement versus leaflet resection techniques on perioperative mortality. Individual study and pooled incidence rate ratios are presented separately for the randomized controlled trial, propensity-matched observational studies, and nonmatched observational studies. The pooled incidence rate ratios with $95 \%$ confidence intervals were calculated using random-effects models. $C I$, Confidence interval; $R C T$, randomized controlled trial. 


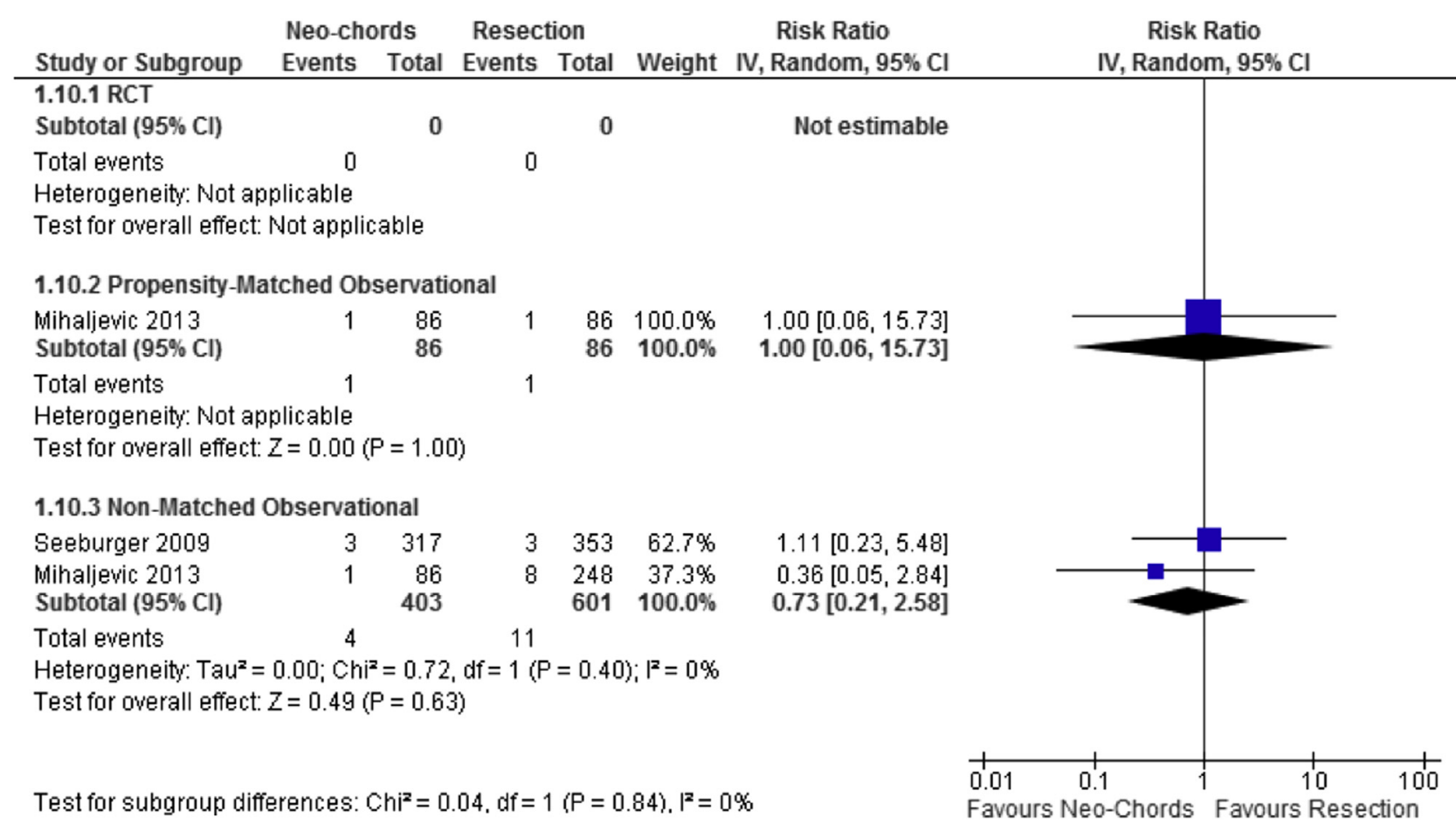

FIGURE E5. Forest plot comparing chordal replacement versus leaflet resection techniques on perioperative stroke. Individual study and pooled incidence rate ratios are presented separately for the randomized controlled trial, propensity-matched observational studies, and nonmatched observational studies. The pooled incidence rate ratios with $95 \%$ confidence intervals were calculated using random-effects models. $C I$, Confidence interval; $R C T$, randomized controlled trial.

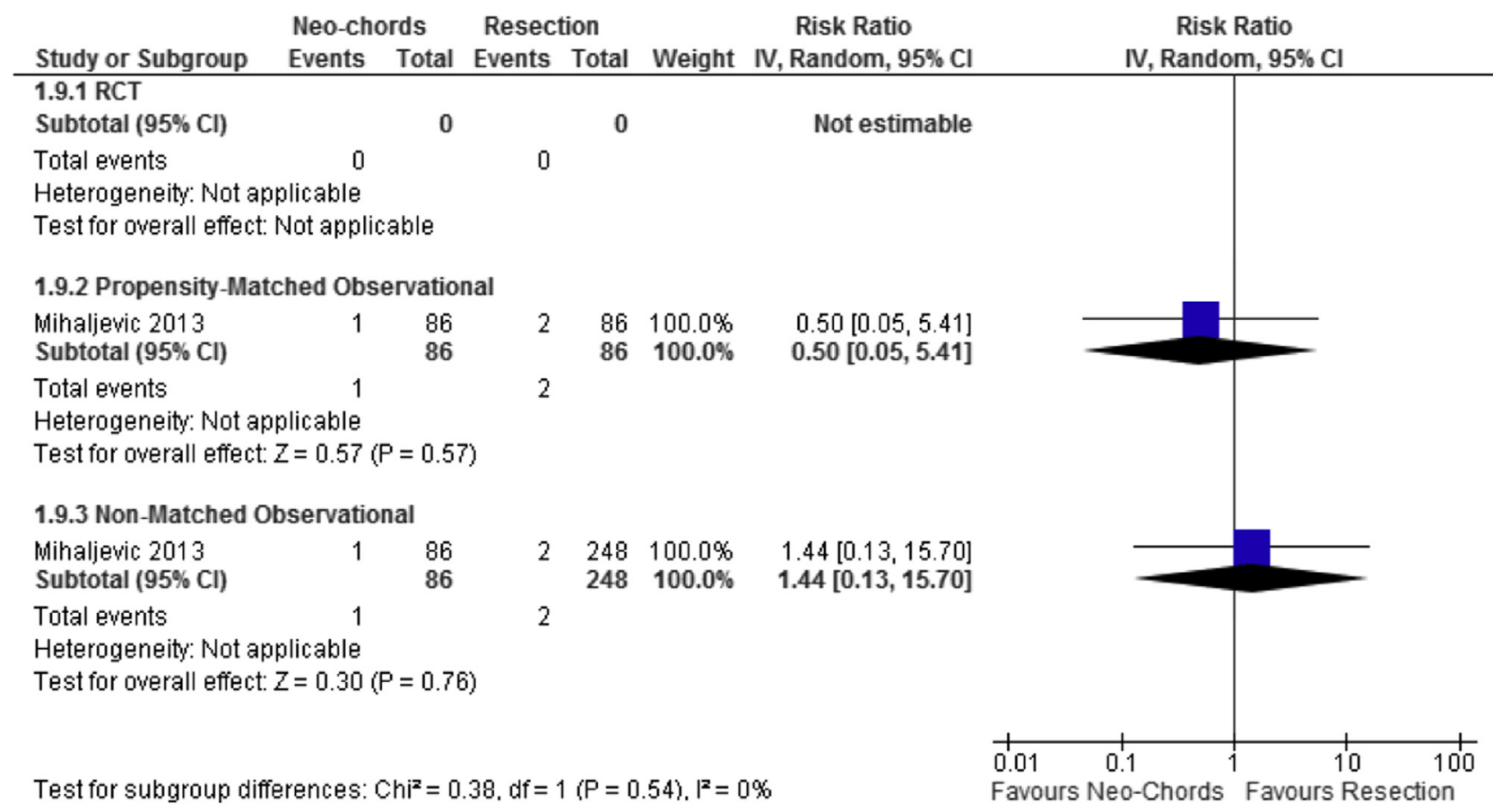

FIGURE E6. Forest plot comparing chordal replacement versus leaflet resection techniques on perioperative myocardial infarction. Individual study and pooled incidence rate ratios are presented separately for the randomized controlled trial, propensity-matched observational studies, and nonmatched observational studies. The pooled incidence rate ratios with $95 \%$ confidence intervals were calculated using random-effects models. $C I$, Confidence interval; $R C T$, randomized controlled trial. 


\begin{tabular}{|c|c|c|c|c|c|c|c|c|c|}
\hline \multirow{3}{*}{$\begin{array}{l}\text { Study or Subgroup } \\
\text { 1.6.1 RCT }\end{array}$} & \multicolumn{3}{|c|}{ Neo-Chord } & \multicolumn{3}{|c|}{ Resection } & \multirow{3}{*}{ Weight } & \multirow{3}{*}{$\begin{array}{l}\text { Mean Difference } \\
\text { IV, Random, } 95 \% \mathrm{Cl}\end{array}$} & \multirow{2}{*}{$\begin{array}{c}\text { Mean Difference } \\
\text { IV, Random, } 95 \% \mathrm{Cl}\end{array}$} \\
\hline & Mean & SD & Total & Mean & SD & Total & & & \\
\hline & & & & & & & & & \\
\hline $\begin{array}{l}\text { Falk } 2008 \\
\text { Subtotal (95\% Cl) }\end{array}$ & 0.2 & 0.5 & $\begin{array}{l}69 \\
69\end{array}$ & 0.1 & 0.3 & $\begin{array}{l}53 \\
53\end{array}$ & $\begin{array}{l}100.0 \% \\
100.0 \%\end{array}$ & $\begin{array}{c}0.10[-0.04,0.24] \\
0.10[-0.04,0.24]\end{array}$ & \\
\hline \multicolumn{10}{|c|}{$\begin{array}{l}\text { Heterogeneity: Not applicable } \\
\text { Test for overall effect: } Z=1.37(P=0.17)\end{array}$} \\
\hline \multicolumn{10}{|c|}{ 1.6.2 Propensity-Matched Observational } \\
\hline $\begin{array}{l}\text { Mihaljewic } 2013 \\
\text { Subtotal }(95 \% \mathrm{Cl})\end{array}$ & 0.25 & 0.64 & $\begin{array}{l}76 \\
76\end{array}$ & 0.14 & 0.42 & $\begin{array}{l}72 \\
72\end{array}$ & $\begin{array}{l}100.0 \% \\
100.0 \%\end{array}$ & $\begin{array}{l}0.11[-0.06,0.28] \\
0.11[-0.06,0.28]\end{array}$ & \\
\hline \multicolumn{10}{|c|}{$\begin{array}{l}\text { Heterogeneity: Not applicable } \\
\text { Test for overall effect: } Z=1.24(P=0.21)\end{array}$} \\
\hline \multicolumn{10}{|c|}{ 1.6.3 Non-Matched Observational } \\
\hline Seeburger 2009 & 0.2 & 0.5 & 317 & 0.4 & 0.6 & 353 & $36.8 \%$ & $-0.20[-0.28,-0.12]$ & - \\
\hline Calafiore 2011 & 0.17 & 0.38 & 36 & 0.21 & 0.42 & 19 & $26.6 \%$ & $-0.04[-0.27,0.19]$ & \\
\hline Silva 2012 & 1 & 1.48 & 28 & 1 & 2.22 & 35 & $4.5 \%$ & $0.00[-0.92,0.92]$ & \\
\hline $\begin{array}{l}\text { Mihaljewic } 2013 \\
\text { Subtotal }(95 \% \mathrm{Cl})\end{array}$ & 0.25 & 0.64 & $\begin{array}{r}76 \\
457\end{array}$ & 0.13 & 0.4 & $\begin{array}{l}219 \\
626\end{array}$ & $\begin{array}{r}32.2 \% \\
100.0 \%\end{array}$ & $\begin{array}{r}0.12[-0.03,0.27] \\
-0.05[-0.25,0.16]\end{array}$ & \\
\hline \multicolumn{10}{|c|}{$\begin{array}{l}\text { Heterogeneity: } \text { Tau }^{2}=0.03 ; \mathrm{Chi}^{2}=13.49, \mathrm{df}=3(\mathrm{P}=0.004) ; \mathrm{I}^{2}=78 \% \\
\text { Test for overall effect: } Z=0.43(\mathrm{P}=0.66)\end{array}$} \\
\hline est for subgroup di & ance & $\mathrm{hi}^{2}$ & & $=2$ & & $\left.\right|^{2}$ & & & $\begin{array}{ccccc}-0.5 & -0.25 & 0 & 0.25 & 0.5 \\
\text { Neo-Chord Lower } & \text { Neo-Chord Higher }\end{array}$ \\
\hline
\end{tabular}

FIGURE E7. Forest plot comparing chordal replacement versus leaflet resection techniques on postprocedural residual mitral regurgitation grade (ranging from 0 [none] to 4 [severe]). Individual study and pooled mean differences are presented separately for the randomized controlled trial, propensity-matched observational studies, and nonmatched observational studies. The pooled mean differences with $95 \%$ confidence intervals were calculated using randomeffects models. $S D$, Standard deviation; $C I$, confidence interval; $R C T$, randomized controlled trial.

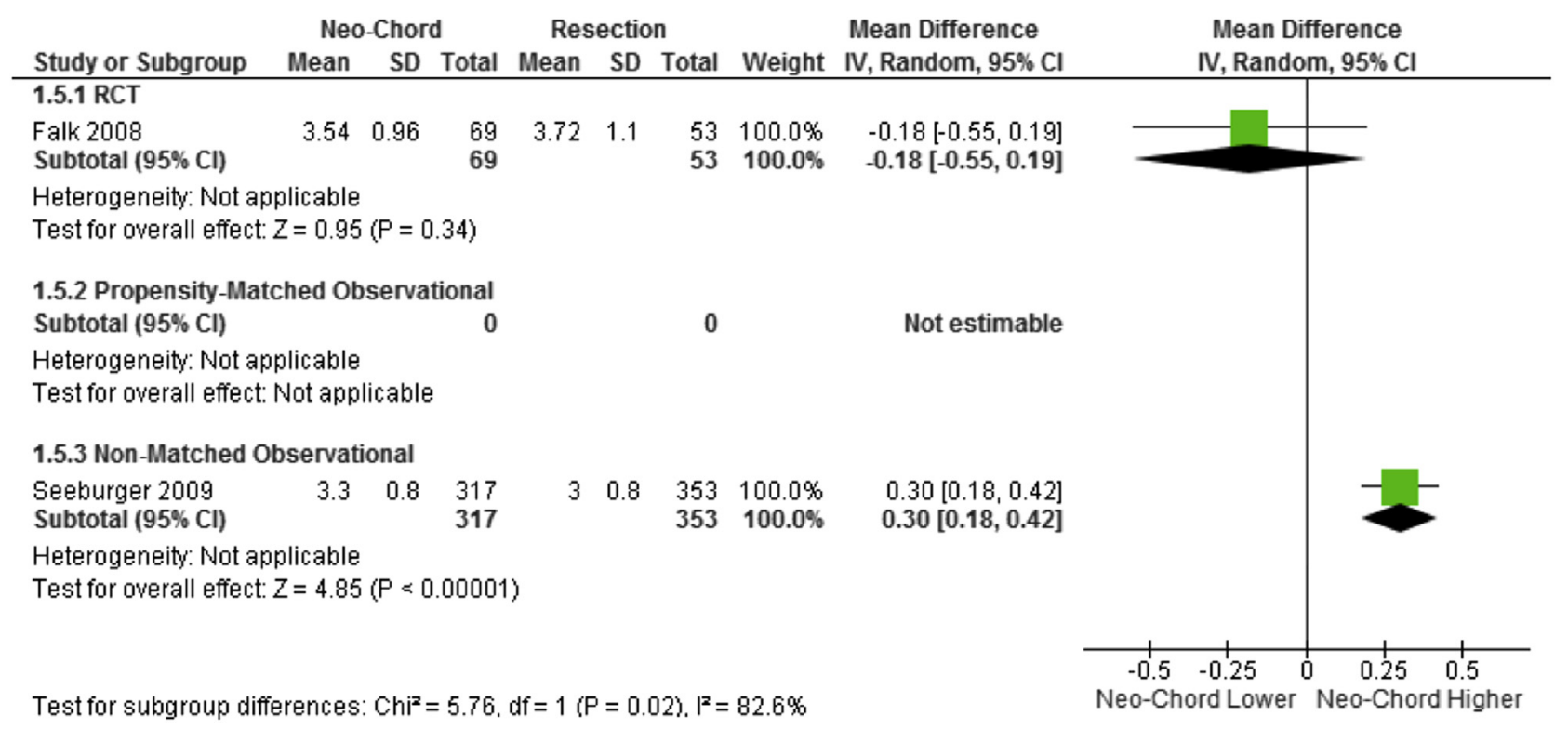

FIGURE E8. Forest plot comparing chordal replacement versus leaflet resection techniques on postprocedural mitral effective orifice area (in $\mathrm{cm}^{2}$ ). Individual study and pooled mean differences are presented separately for the randomized controlled trial, propensity-matched observational studies, and nonmatched observational studies. The pooled mean differences with $95 \%$ confidence intervals were calculated using random-effects models. SD, Standard deviation; $C I$, confidence interval; $R C T$, randomized controlled trial. 


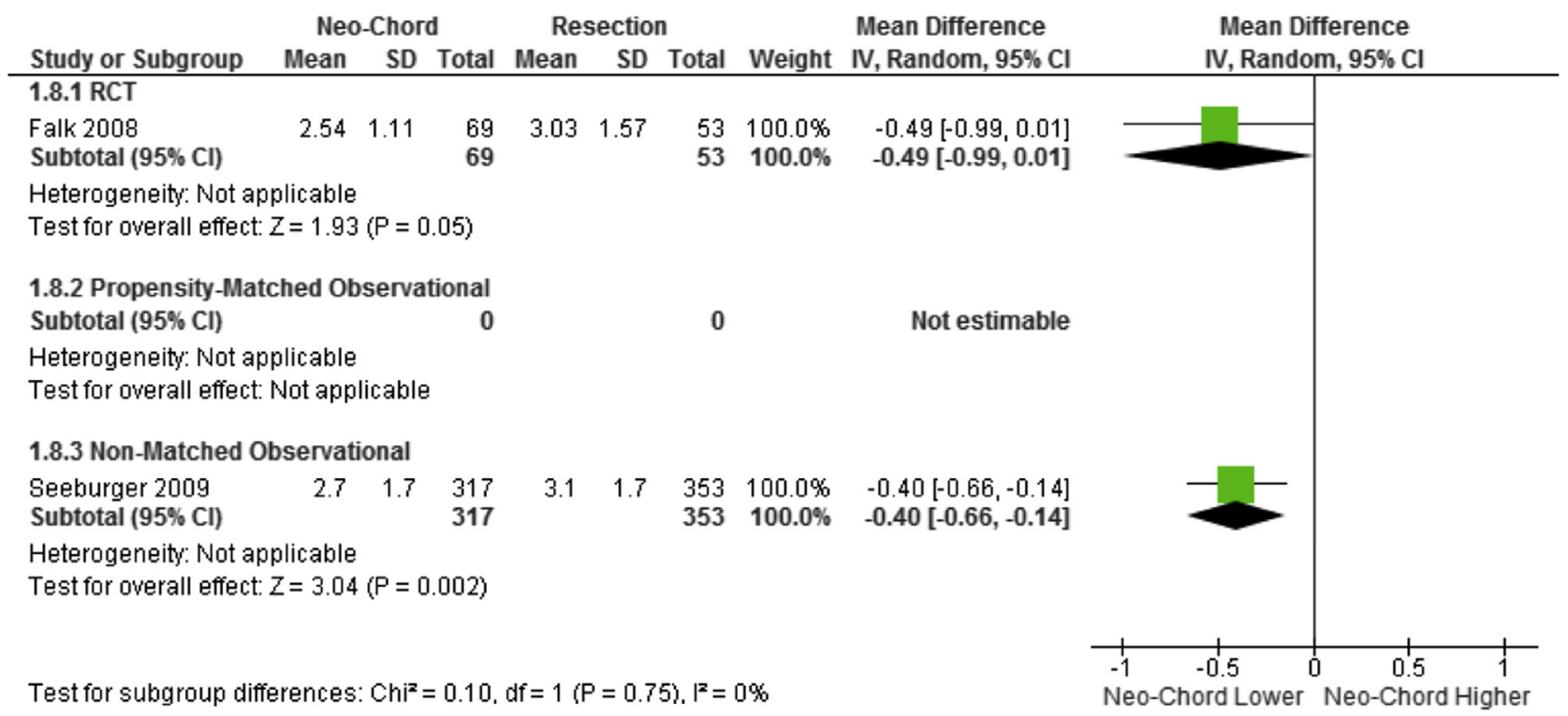

FIGURE E9. Forest plot comparing chordal replacement versus leaflet resection techniques on post-procedural mean mitral gradients (in mmHg). Individual study and pooled mean differences are presented separately for the randomized controlled trial, propensity-matched observational studies, and nonmatched observational studies. The pooled mean differences with $95 \%$ confidence intervals were calculated using random-effects models. $S D$, Standard deviation; $C I$, confidence interval; $R C T$, randomized controlled trial.

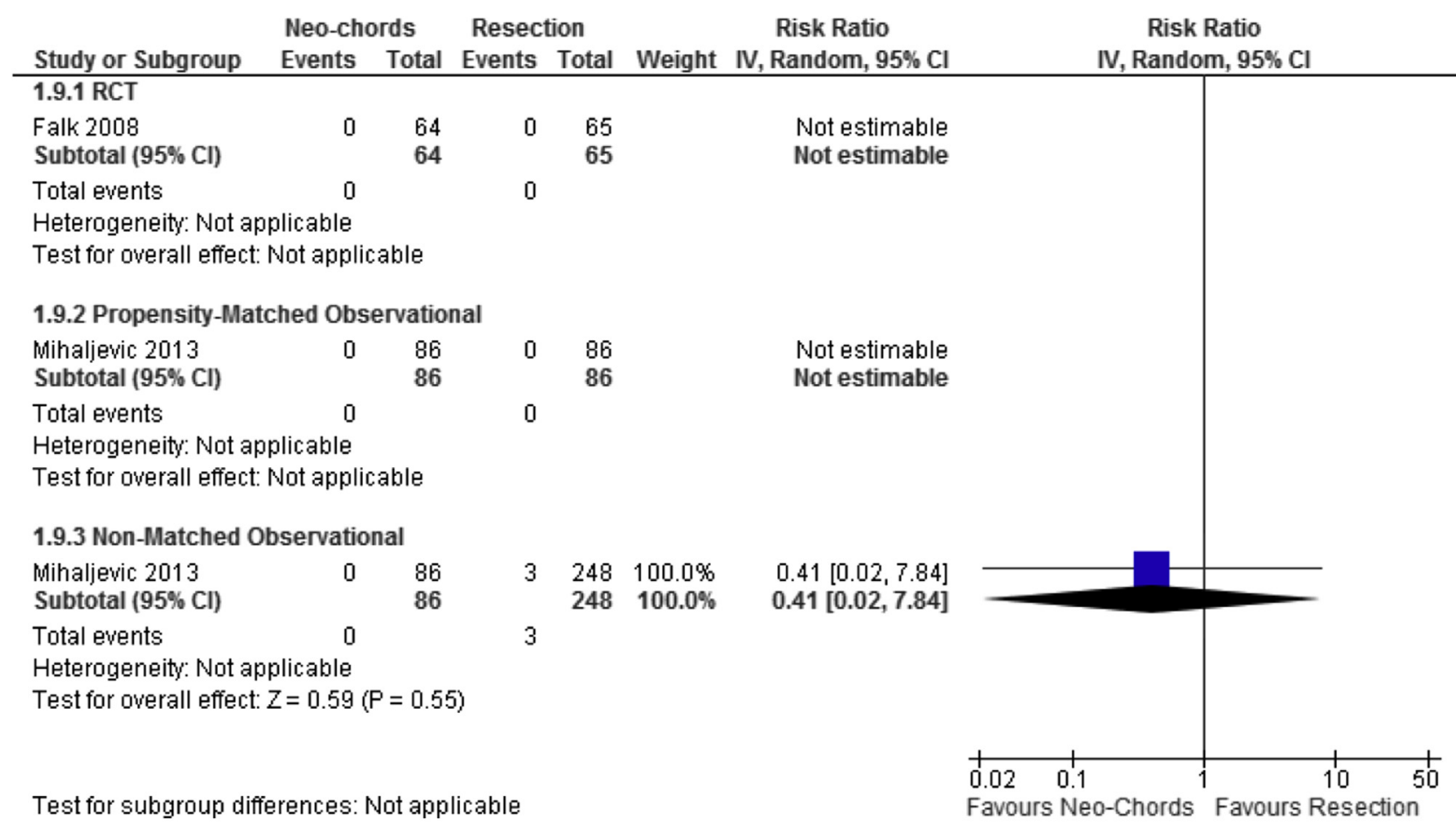

FIGURE E10. Forest plot comparing chordal replacement versus leaflet resection techniques on the incidence of postprocedural systolic anterior motion. Individual study and pooled incidence rate ratios are presented separately for the randomized controlled trial, propensity-matched observational studies, and nonmatched observational studies. The pooled incidence rate ratios with $95 \%$ confidence intervals were calculated using random-effects models. $C I$, Confidence interval; $R C T$, randomized controlled trial. 


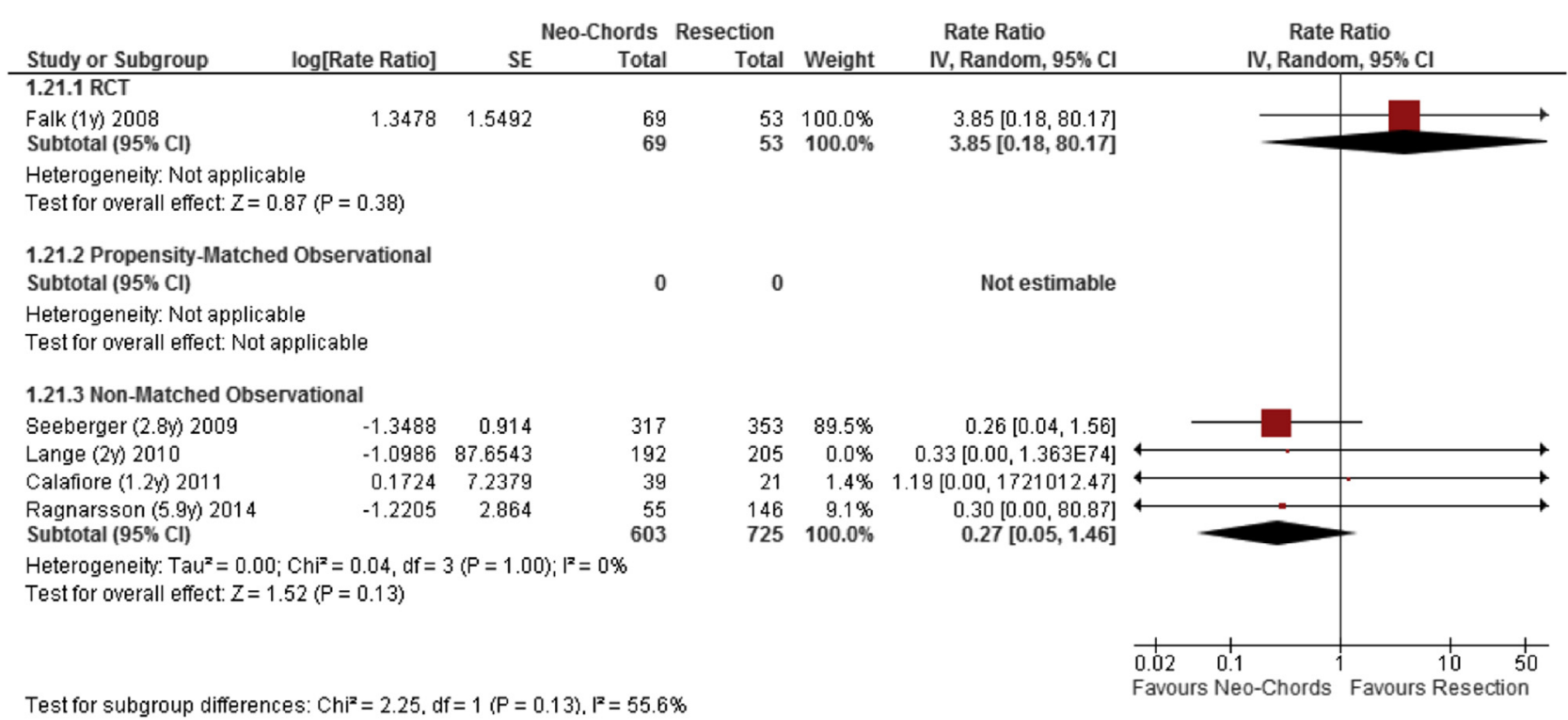

FIGURE E11. Forest plot comparing chordal replacement versus leaflet resection techniques on freedom from all-cause mortality at follow-up. Individual study and pooled incidence rate ratios are presented separately for the randomized controlled trial, propensity-matched observational studies, and nonmatched observational studies. The pooled incidence rate ratios with $95 \%$ confidence intervals were calculated using random-effects models. Mean overall follow up durations are provided in brackets after the author's name for each study. $S E$, Standard error; $C I$, confidence interval; $R C T$, randomized controlled trial.

\begin{tabular}{|c|c|c|c|c|c|c|c|c|c|c|}
\hline \multirow{3}{*}{$\frac{\text { Study or Subgroup }}{1.16 .1 \text { RCT }}$} & \multicolumn{3}{|c|}{ Neo-Chord } & \multicolumn{3}{|c|}{ Resection } & \multirow{3}{*}{ Weight } & \multirow{2}{*}{$\begin{array}{l}\text { Mean Difference } \\
\text { IV, Random, } 95 \% \mathrm{Cl}\end{array}$} & \multirow{2}{*}{\multicolumn{2}{|c|}{$\begin{array}{c}\text { Mean Difference } \\
\text { IV, Random, } 95 \% \mathrm{Cl}\end{array}$}} \\
\hline & Mean & SD & Total & Mean & SD & Total & & & & \\
\hline & & & & & & & & & & \\
\hline Falk $(0.5 y) 2008$ & 60.4 & 7.9 & 42 & 57.3 & 7.9 & 34 & $0.0 \%$ & $3.10[-0.47,6.67]$ & & \\
\hline $\begin{array}{l}\text { Falk (1y) } 2008 \\
\text { Subtotal }(95 \% \mathrm{Cl})\end{array}$ & 62.9 & 8.3 & $\begin{array}{l}30 \\
30\end{array}$ & 59 & 12.3 & $\begin{array}{l}20 \\
20\end{array}$ & $\begin{array}{l}5.0 \% \\
5.0 \%\end{array}$ & $\begin{array}{c}3.90[-2.25,10.05] \\
3.90[-2.25,10.05]\end{array}$ & & \\
\hline \multicolumn{11}{|c|}{$\begin{array}{l}\text { Heterogeneity: Not applicable } \\
\text { Test for overall effect: } Z=1.24(P=0.21)\end{array}$} \\
\hline \multicolumn{11}{|c|}{ 1.16.2 Propensity-Matched Observational } \\
\hline Subtotal $(95 \% \mathrm{Cl})$ & & & $\mathbf{0}$ & & & 0 & & Not estimable & & \\
\hline \multicolumn{11}{|c|}{$\begin{array}{l}\text { Heterogeneity: Not applicable } \\
\text { Test for overall effect: Not applicable }\end{array}$} \\
\hline \multicolumn{11}{|c|}{ 1.16.3 Non-Matched Observational } \\
\hline Lange (1.6y) 2010 & 57 & 7.4 & 166 & 57 & 6.2 & 171 & $88.7 \%$ & $0.00[-1.46,1.46]$ & & \\
\hline $\begin{array}{l}\text { Silva (3.1y) } 2012 \\
\text { Subtotal }(95 \% \mathrm{Cl})\end{array}$ & 64.7 & 12.3 & $\begin{array}{r}28 \\
194\end{array}$ & 66.2 & 9.2 & $\begin{array}{r}35 \\
206\end{array}$ & $\begin{array}{r}6.3 \% \\
95.0 \%\end{array}$ & $\begin{array}{l}-1.50[-6.98,3.98] \\
-0.10[-1.51,1.31]\end{array}$ & & \\
\hline \multicolumn{11}{|c|}{$\begin{array}{l}\text { Heterogeneity: } \text { Tau }^{2}=0.00 ; \mathrm{Chi}^{2}=0.27, \mathrm{df}=1(\mathrm{P}=0.60) ; \mathrm{I}^{2}=0 \% \\
\text { Test for overall effect: } Z=0.14(\mathrm{P}=0.89)\end{array}$} \\
\hline Total $(95 \% \mathrm{Cl})$ & & & 224 & & & 226 & $100.0 \%$ & $0.10[-1.27,1.48]$ & & \\
\hline \multicolumn{9}{|c|}{$\begin{array}{l}\text { Heterogeneity: } \text { Tau }^{2}=0.00 ; \mathrm{Chi}^{2}=1.81, \mathrm{df}=2(\mathrm{P}=0.40) ; \mathrm{I}^{2}=0 \% \\
\text { Test for overall effect: } \mathrm{Z}=0.14(\mathrm{P}=0.89) \\
\text { Test for subgroup differences: } \mathrm{Ch}^{2}=1.54 . \mathrm{df}=1(\mathrm{P}=0.21), \mathrm{I}^{2}=3\end{array}$} & $\begin{array}{ccc} & 1 & 1 \\
-10 & -5 & 0 \\
\text { Neo-Chord Lower } & \text { Neo-Cho }\end{array}$ & $\begin{array}{l}15 \\
5 \\
\text { ord Higher }\end{array}$ \\
\hline
\end{tabular}

FIGURE E12. Forest plot comparing chordal replacement versus leaflet resection techniques on left ventricular ejection fraction at follow-up (in \%). Individual study and pooled mean differences are presented separately for the randomized controlled trial, propensity-matched observational studies, and nonmatched observational studies. The pooled mean differences with $95 \%$ confidence intervals were calculated using random-effects models. Mean overall follow up durations are provided in brackets after the author's name for each study. $S D$, Standard deviation; $C I$, confidence interval; $R C T$, randomized controlled trial. 


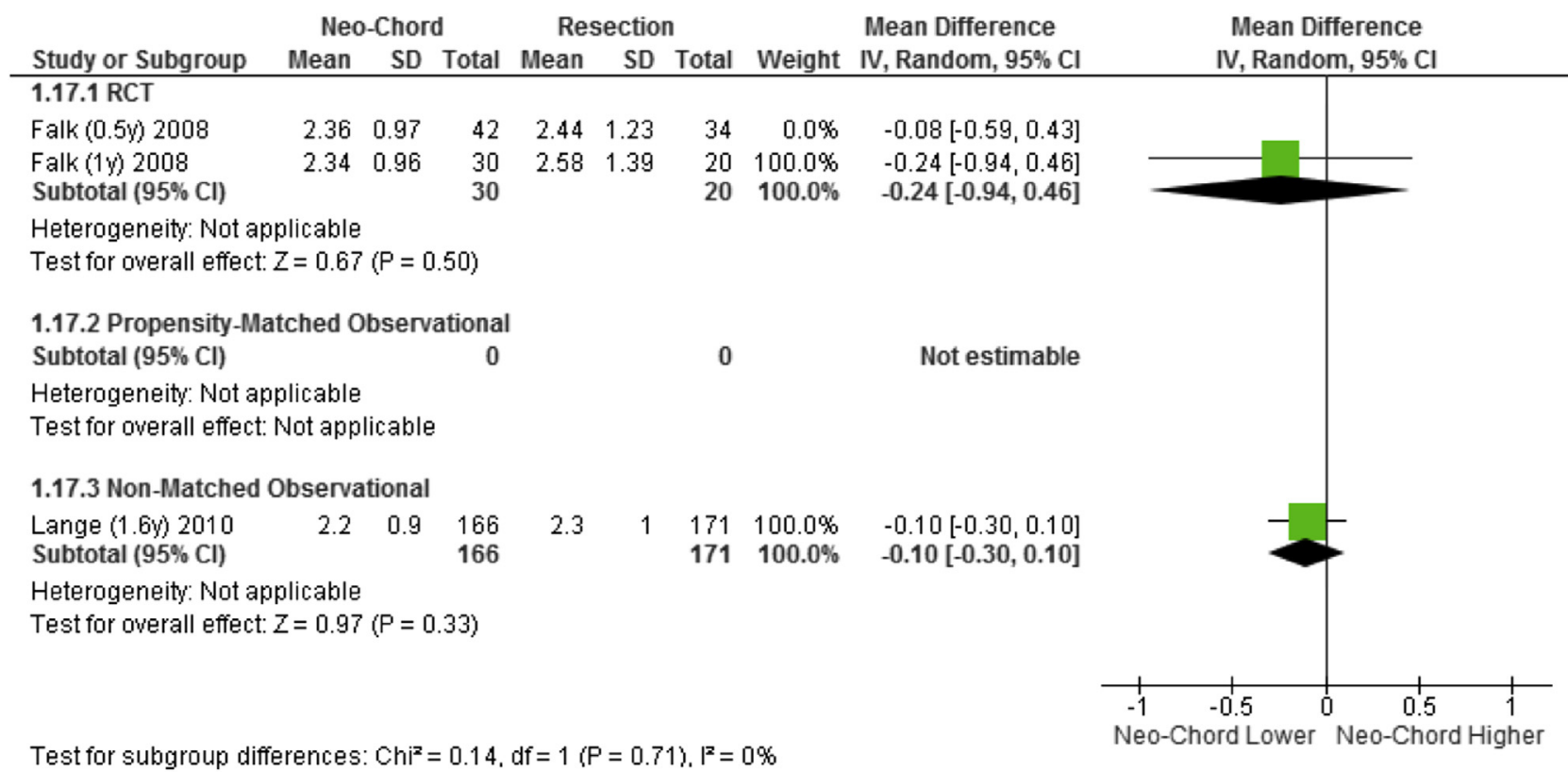

FIGURE E13. Forest plot comparing chordal replacement versus leaflet resection techniques on mean mitral gradients at follow-up (in mmHg). Individual study and pooled mean differences are presented separately for the randomized controlled trial, propensity-matched observational studies, and nonmatched observational studies. The pooled mean differences with $95 \%$ confidence intervals were calculated using random-effects models. Mean overall follow-up durations are provided in brackets after the author's name for each study. $S D$, Standard deviation; $C I$, confidence interval; $R C T$, randomized controlled trial.

TABLE E1. Quality assessment of the included randomized controlled trial (Falk et al, $2008^{25} ; 2$ centers, 129 patients, Germany, 2005 to 2007 ), Cochrane Collaboration Risk of Bias

\begin{tabular}{|c|c|c|}
\hline Bias & Authors' judgment & Support for judgment \\
\hline Random sequence generation (selection bias) & Unclear risk & $\begin{array}{l}\text { Computer-generated random numbers but only } 129 \text { of } 297(43 \%) \\
\text { patients meeting inclusion criteria enrolled }\end{array}$ \\
\hline Allocation concealment (selection bias) & Low risk & Sealed envelopes \\
\hline Blinding of participants and personnel (performance bias) & High risk & Not blinded \\
\hline Blinding of outcome assessment (detection bias) & High risk & Not blinded \\
\hline Incomplete outcome data (attrition bias) & High risk & $\begin{array}{l}\text { Seven dropouts who received both interventions excluded, and } \\
\text { echocardiographic follow-up was incomplete: only } 59 \% \\
\text { complete at } 6 \text { months and } 31 \% \text { complete at } 1 \text { year. }\end{array}$ \\
\hline Selective reporting (reporting bias) & Low risk & Reported important outcomes \\
\hline Other bias & High risk & $\begin{array}{l}\text { No intention-to-treat analysis; } 12 \text { of } 129(9.3 \%) \text { crossed over and } \\
\text { were analyzed as treated, and } 7 \text { of } 129(5.4 \%) \text { who received both } \\
\text { interventions were excluded from the analysis. }\end{array}$ \\
\hline Overall & High risk & At least 1 individual category judged to be at high risk of bias. \\
\hline
\end{tabular}


TABLE E2. Characteristics of included observational studies

\begin{tabular}{|c|c|c|c|c|c|}
\hline $\begin{array}{l}\text { Study, country, enrollment years; } \\
\text { mean FU duration; } \\
\text { FU completeness }\end{array}$ & $\begin{array}{l}\text { No. of } \\
\text { centers }\end{array}$ & $\begin{array}{c}\text { No. of } \\
\text { patients }\end{array}$ & Design & Concurrent control & Comparable baseline \\
\hline $\begin{array}{l}\text { Mihaljevic et al, } 2013,{ }^{29} \text { UAE, } \\
\text { 2007-2010; hospital discharge; } \\
100 \%\end{array}$ & 1 & 334 & Retrospective & $\begin{array}{c}\text { Yes } \\
\text { (surgeon discretion) }\end{array}$ & $\begin{array}{l}\text { No (neo-chordae patients more frequently } \\
\text { had } 2 \text { or } 3 \text { prolapsing posterior leaflet } \\
\text { segments, and had more diabetes but less } \\
\text { carotid disease). These differences } \\
\text { persisted }(P<.10) \text { despite propensity } \\
\text { matching. }\end{array}$ \\
\hline $\begin{array}{l}\text { Seeburger et al, } 2009,{ }^{31} \text { Germany, } \\
1999-2008 ; 2.8 \pm 2.2 \text { years; } 99 \%\end{array}$ & 1 & 670 & Retrospective & $\begin{array}{c}\text { Yes } \\
\text { (surgeon discretion) }\end{array}$ & $\begin{array}{l}\text { No (neo-chordae patients had lower mean } \\
\text { EuroSCORE, less previous cardiac } \\
\text { operations, less endocarditis, but more } \\
\text { frequently had a calcified annulus and } \\
\text { elongated chordae). }\end{array}$ \\
\hline $\begin{array}{l}\text { Lange et al, } 2010,{ }^{28} \text { Germany, } \\
\quad 2000-2007 ; 1.9 \pm 1.4 \text { years; } 98 \%\end{array}$ & 1 & 397 & Retrospective & $\begin{array}{c}\text { Yes } \\
\text { (surgeon discretion) }\end{array}$ & $\begin{array}{l}\text { No (neo-chordae patients were younger and } \\
\text { had less sinus rhythm) }\end{array}$ \\
\hline $\begin{array}{l}\text { Calafiore et al, } 2011,{ }^{26} \text { Italy, } \\
\text { 2006-2009; } 2.3 \pm 0.9 \text { years; } 100 \%\end{array}$ & 1 & 60 & Retrospective & $\begin{array}{c}\text { Yes } \\
\text { (surgeon discretion) }\end{array}$ & $\begin{array}{l}\text { Yes (although possibly underpowered to } \\
\text { detect differences, because neo-chordae } \\
\text { were used selectively for fibroelastic } \\
\text { deficiency with isolated P2 prolapse, need } \\
\text { for excessive P2 resection, dominant or } \\
\text { codominant circumflex artery, and/or } \\
\text { young patients without preoperative } \\
\text { coronary angiography) }\end{array}$ \\
\hline $\begin{array}{l}\text { Silva et al, } 2012,{ }^{32} \text { Spain, } \\
2005-2010 ; 3.1 \pm 1.6 \text { years; } 98 \%\end{array}$ & 1 & 63 & Retrospective & $\begin{array}{c}\text { Yes } \\
\text { (surgeon discretion) }\end{array}$ & $\begin{array}{l}\text { No (neo-chordae patients had higher } \\
\text { pulmonary artery pressure) }\end{array}$ \\
\hline $\begin{array}{l}\text { Ragnarsson et al, } 2014,{ }^{30} \text { Sweden } \\
\text { and Denmark, } 1998-2012 \\
5.9 \pm 3.9 \text { years; } 100 \%\end{array}$ & 2 & $201 / 224 *$ & Retrospective & $\begin{array}{c}\text { Yes } \\
\text { (surgeon discretion) }\end{array}$ & $\begin{array}{l}\text { No (neo-chordae patients had less NYHA } \\
\text { class III-IV and more minithoracotomy) }\end{array}$ \\
\hline $\begin{array}{l}\text { Imasaka et al, 2015, }{ }^{27} \text { Japan, } \\
\text { 2006-2014; } 1 \text { month (all patients); } \\
100 \%\end{array}$ & 1 & 72 & Retrospective & $\begin{array}{l}\text { Yes } \\
\text { (surgeon discretion) }\end{array}$ & $\begin{array}{l}\text { No (neo-chordae patients had higher } \\
\text { pulmonary artery pressure, underwent } \\
\text { more concomitant tricuspid } \\
\text { annuloplasties, more superior transseptal } \\
\text { vs right-sided left atrial approach, and } \\
\text { more Physio vs Cosgrove [Edwards } \\
\text { Lifesciences] rings) }\end{array}$ \\
\hline
\end{tabular}

FU, Follow-up; UAE, United Arab Emirates; NYHA, New York Heart Association. *Excluded 9 patients requiring mitral valve replacement and 14 patients treated with both neochordae and leaflet resection. 


\begin{tabular}{|c|c|c|c|c|c|c|c|c|}
\hline Quality assessment criteria & Acceptable & $\begin{array}{l}\text { Seeburger } \\
\text { et al, } \mathbf{2 0 0 9}^{31}\end{array}$ & $\begin{array}{c}\text { Lange } \\
\text { et al, } \mathbf{2 0 1 0}^{28}\end{array}$ & $\begin{array}{c}\text { Calafiore } \\
\text { et al, 2011 }\end{array}$ & $\begin{array}{c}\text { Silva } \\
\text { et al, 2012 }\end{array}$ & $\begin{array}{l}\text { Mihaljevic } \\
\text { et al, } \mathbf{2 0 1 3}^{29}\end{array}$ & $\begin{array}{l}\text { Ragnarsson } \\
\text { et al, 2014 }\end{array}$ & $\begin{array}{c}\text { Imasaka } \\
\text { et al, } \mathbf{2 0 1 5}^{27}\end{array}$ \\
\hline $\begin{array}{l}\text { Selection } \\
\text { Representativeness of exposed } \\
\text { cohort? }\end{array}$ & $\begin{array}{l}\text { Representative of average adult in the } \\
\text { community (vs selected group or } \\
\text { no description) }\end{array}$ & Yes & Yes & Yes & Yes & Yes & Yes & Yes \\
\hline $\begin{array}{l}\text { Selection of the nonexposed } \\
\text { cohort? }\end{array}$ & $\begin{array}{l}\text { Drawn from same community as } \\
\text { cohort (vs drawn from different } \\
\text { source or no description) }\end{array}$ & Yes & Yes & Yes & Yes & Yes & Yes & Yes \\
\hline Ascertainment of exposure? & $\begin{array}{l}\text { Secured (eg, surgical) records or } \\
\text { structured interview (vs self- } \\
\text { report or no description) }\end{array}$ & Yes & Yes & Yes & Yes & Yes & Yes & Yes \\
\hline $\begin{array}{l}\text { Demonstration that outcome of } \\
\text { interest was not present at start } \\
\text { of study? }\end{array}$ & Yes & Yes & Yes & Yes & Yes & Yes & Yes & Yes \\
\hline \multicolumn{9}{|l|}{ Comparability } \\
\hline $\begin{array}{l}\text { Study controls for most important } \\
\text { factor? }\end{array}$ & $\begin{array}{l}\text { Yes for severity of posterior mitral } \\
\text { valve degeneration }\end{array}$ & No & No & No & No & No & No & No \\
\hline $\begin{array}{l}\text { Study controls for additional } \\
\text { factors? }\end{array}$ & Yes for comorbidities & No & No & No & No & No & No & No \\
\hline \multicolumn{9}{|l|}{ Outcome } \\
\hline Assessment of outcome? & $\begin{array}{l}\text { Objective assessment or surgical } \\
\text { record (vs self-report or no } \\
\text { description) }\end{array}$ & Yes & Yes & Yes & Yes & Yes & Yes & Yes \\
\hline $\begin{array}{l}\text { Was follow-up sufficiently long for } \\
\text { outcome to occur? }\end{array}$ & $\geq 1.5 \mathrm{y}$ & Yes $(2.8 \mathrm{y})$ & Yes $(1.9 \mathrm{y})$ & Yes $(2.3 \mathrm{y})$ & Yes $(3.1 \mathrm{y})$ & No (in-hospital) & Yes $(5.9 \mathrm{y})$ & No $(1 \mathrm{mo})$ \\
\hline Adequacy of follow-up of cohorts? & $<5 \%$ subjects lost to follow-up & Yes & Yes & Yes & Yes & Yes & Yes & Yes \\
\hline Overall quality score (maximum, 9) & & 7 & 7 & 7 & 7 & 6 & 7 & 6 \\
\hline
\end{tabular}

